\title{
Review \\ Advances in the Prophylaxis of Respiratory Infections by the Nasal and the Oromucosal Route: Relevance to the Fight with the SARS-CoV-2 Pandemic
}

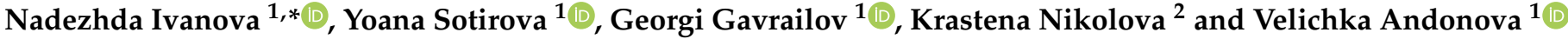 \\ 1 Department of Pharmaceutical Technologies, Faculty of Pharmacy, Medical University of Varna, 55 Marin \\ Drinov Str., 9000 Varna, Bulgaria; yoana.sotirova@mu-varna.bg (Y.S.); georgi.gavrailov@mu-varna.bg (G.G.); \\ velichka.andonova@mu-varna.bg (V.A.) \\ 2 Department of Physics and Biophysics, Faculty of Pharmacy, Medical University of Varna, 55 Marin Drinov \\ Str., 9000 Varna, Bulgaria; krastena.nikolova@mu-varna.bg \\ * Correspondence: nadejda.ivanova@mu-varna.bg
}

Citation: Ivanova, N.; Sotirova, Y.; Gavrailov, G.; Nikolova, K.;

Andonova, V. Advances in the Prophylaxis of Respiratory Infections by the Nasal and the Oromucosal Route: Relevance to the Fight with the SARS-CoV-2 Pandemic Pharmaceutics 2022, 14, 530. https://doi.org/10.3390/ pharmaceutics 14030530

Academic Editors: Luis Cobra Branco and Miguel Santos

Received: 22 December 2021 Accepted: 23 February 2022 Published: 27 February 2022

Publisher's Note: MDPI stays neutral with regard to jurisdictional claims in published maps and institutional affiliations.

Copyright: (C) 2022 by the authors. Licensee MDPI, Basel, Switzerland. This article is an open access article distributed under the terms and conditions of the Creative Commons Attribution (CC BY) license (https:// creativecommons.org/licenses/by/ $4.0 /)$.

\begin{abstract}
In this time of COVID-19 pandemic, the strategies for prevention of the infection are a primary concern. Looking more globally on the subject and acknowledging the high degree of misuse of protective face masks from the population, we focused this review on alternative pharmaceutical developments eligible for self-defense against respiratory infections. In particular, the attention herein is directed to the nasal and oromucosal formulations intended to boost the local immunity, neutralize or mechanically "trap" the pathogens at the site of entry (nose or mouth). The current work presents a critical review of the contemporary methods of immune- and chemoprophylaxis and their suitability and applicability in topical mucosal dosage forms for SARS-CoV-2 prophylaxis.
\end{abstract}

Keywords: COVID-19; SARS-CoV-2; respiratory infections; prophylaxis; nasal drug delivery; mucosal drug delivery; protective nasal sprays; protective oral sprays; mucoadhesive dosage forms; antiviral drugs

\section{Introduction}

Respiratory tract infections (RTIs) are common and acquired predominantly via airborne and respiratory droplet transmission mechanisms [1,2]. One such infection-the SARS-CoV-2 - continues to spread to the level of a pandemic [3] and provokes scientists to think critically, explore, question, and hypothesize in all aspects of the resultant ongoing crisis-from medical and pharmaceutical to social, psychological, economic, etc. At the same time, science today is advanced and progressive and has a vast resource to react flexibly and repurpose developments to suit the current urgencies and needs. The recent stepping into the market of new-generation mRNA vaccines for COVID-19 [4-6] is the biggest but far from the only proof of that. It is reasonable to assume that much of the reinforced research and development during the pandemic will also retain its value and find its contribution beyond the COVID-19 crisis. The current survey is focused on innovative developments for protection against RTIs, with an emphasis on nasal and oromucosal pharmaceutical formulations, eligible for self-use by the patients. The topic is of global and universal interest and most relevant for the aim of protection of individuals who encounter high risk for infection in their social environment-for example, by traveling, visiting a medical facility, and participating in public events.

The adhesion of a pathogenic microorganism to the site of entry in the human body is a determinative step for its further absorption, replication, and ability to cause disease [7]. The main entry sites for the most common bacteria and viruses are the mucosal surfaces of the nasal and oral cavity, the eyelids, and the rectal and vaginal tracts [7,8]. Although the aforementioned mucosal tissues differ in structure and function, they also have much 
in common. For instance, they all represent a far less effective barrier for pathogenic microorganisms than the skin and possess a morphology much more susceptible to the occurrence of microlesions. The latter are of great importance for the generalization of a locally arisen infection $[8,9]$. However, the mucosal tissue is covered by a mucus gel, which has a biophysical protective function on the underlying mucosal epithelium $[10,11]$. In terms of microbial contamination of the mucosal surface, the mucus and the mucociliary clearance play a key role in limiting the time of retention of the pathogen on the site of entry and its permeation to the lymph and blood flow [12].

Mucoadhesive polymers are widely used for their ability to attach to mucous surfaces and ensure prolonged contact of a drug-delivery system with the site of application [13]. If obtained with good spreadability, the mucoadhesive forms could provide a "shielding" film on the mucosa, enhancing its defensive properties against pathogens [14]. The use of mucoadhesive polymers in proper concentration for nasal and oromucosal administration is considered a novel and strategic approach for the aim of mucosal integrity restoration and prevention of respiratory infections [15-17]. Moreover, the introduction of active compounds with antimicrobial properties in mucoadhesive vehicles is highly relevant to the search for more efficient approaches in the prophylaxis of RTIs [14,15]. Since respired air is primarily routed through the nose, the nasal formulations are the ones of most importance [15].

\section{An Insight of the Early Phases of Respiratory Tract Infections (RTIs)}

The most common causes for primary RTIs are viruses [17,18] (Influenza viruses, Coronaviruses, Rhinoviruses, Human metapneumovirus, Parainfluenza virus, Respiratory Syncytial Virus (RSV), Adenoviruses [19,20]) and less frequently bacteria (S. pneumoniae, H. influenzae, Moraxella catarrhalis [21]). The Coronaviruses (including the lately identified SARS-CoV-2), and likewise the other pathogenic microorganisms in this group, transmit in the community predominantly via four mechanisms: (1) airborne—via small respiratory droplets, "droplet nuclei", or dust (aerosol transmission), (2) respiratory droplet mechanism (via large respiratory droplets generated through coughing or sneezing), (3) direct contact (person-to-person transmission), and (4) indirect contact-transmission from an animate or inanimate (fomite) source $[1,15,22,23]$. Regardless of the route of transmittance, the upper respiratory tract is the most likely site of their entry into the human body [24].

The early stages of the viral and bacterial pathogenesis include adherence and implantation of the pathogenic microorganism at the portal of entry, viz., the respiratory mucosa $[7,21,25,26]$. The first-line, nonspecific natural opposing mechanisms to pathogen adherence are represented by the mucus secretion (covering the underlying tissue) and its motility, driven by the respiratory cilia (mucociliary clearance) [26], and the rapid replacement of mucosal epithelial cells (completed in about every 36-48 h) [21,25]. These forms of local resistance work in favor of hindered diffusion and shorter contact time of the pathogen with the living tissue. Some of the main prerequisites for unsuccessful timely pathogen clearance at this point are the existence of an accompanying infection [21] or chronic disease [26], compromised integrity of the mucosa (microlesions or wounds $[21,25]$ ), and smoking [26-28]. In addition, some viruses and bacteria express virulence factors that affect the mucociliary clearance efficacy and thus ease their own adherence [26]. Many pathogenic microbes, including Streptococcus pneumoniae, Haemophilus influenzae, Coronavirus, Influenza, RSV and Rhinovirus, are known to disrupt the ciliary beating and coordination [29-37].

If the mucus barrier is overcome, further implantation of the virus or bacteria is determined by the direct contact with the mucosal epithelia and bonding $[7,21,25]$. The attachment for most Gram-negative bacteria occurs via pili (fimbriae) [25] —-thin, hair-like protein appendages on their surface that bind to specific membrane factors on the host cells $[21,25,38]$. Similarly, viruses use specific protein domains to establish a connection with certain receptors of the host cells; further on, they enter the cytoplasm (by endocytosis), access the cell's synthetic apparatus, and use it for their own replication [7,39]. In general, the virulence factors expressed by the pathogen to serve for its attachment to 
the host cells are termed "adhesins" [40,41]. The role of a leading adhesin for all Coronaviruses is played by the surface glycoprotein Spike (S-protein) and its receptor-binding domain (RBD) (Figure 1) [15,39]. Examples of known targeted host receptors are the angiotensin-converting enzyme 2 (ACE2) for SARS-CoV and SARS-CoV-2 [42], dipeptidyl peptidase-4 (DPP4) for Middle-East Respiratory Syndrome Coronavirus (MERS-CoV) [43], human aminopeptidase N (CD13) for Human Coronavirus subtype HCoV-E229 [32], human leucocyte antigen class I (HLA class I) and sialic acid for Human Coronavirus subtype HCoV-OC43 [44-46], sialic acid for Influenza type A and B [46-48], intercellular adhesion molecule 1 (ICAM-1) for Rhinovirus [34,46,49,50], and CX3C chemokine receptor 1 (CX3CR 1) for RSV [36,37]. The genetically specified expression of these receptors on the cell membranes of differentiated cells dictates the cell/tissue tropism and spread mechanisms of the pathogen [39]. The ACE2 receptor for SARS-CoV-2, for instance, is abundant among the respiratory epithelial cells (with the ciliated bronchial epithelial cells and type II pneumocytes being highly enriched $[42,51])$, the oral and ocular mucosa, the salivary glands, and the intestinal enterocytes [52]. The stages of pathogen implantation and local replication are usually asymptomatic and related to the incubation period, peculiar for every infectious disease [7]. The onset of the symptomatic phase and the severity of the infection are determined by the pathogen's virulence, infectivity, and initial dose exposure, as well as by the host resistance (immunity—specific and nonspecific; local or systemic) $[7,25]$.

Building of a physical barrier that limits the viral access to cell entry factors Competitive binding to viral adhesin (RBD)

Competitive binding to cell entry factors (ACE2 receptor and/or I'MI'RSS2)

Induction of structural disorders in the ACli2 receptor

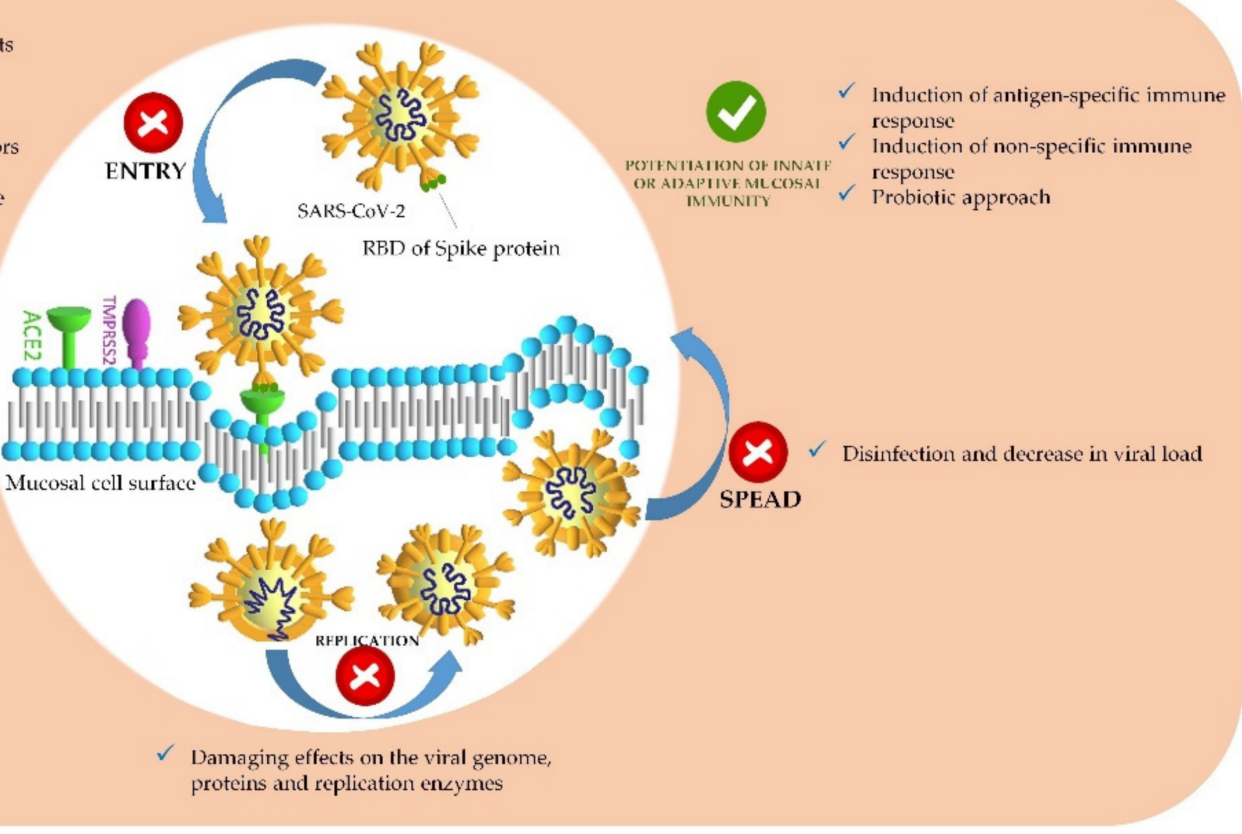

Figure 1. Infectious cycle of SARS-CoV-2 and niches for prevention of the infection.

\section{The Upper Respiratory Tract (URT)}

The upper airway is presented by the nasal and oral cavity, the pharynx, and the larynx. Among its most important physiological functions is to deliver the inhaled air to the tracheal tree in an adjusted state-filtrated, warmed, and humidified [53]. The external respiration takes place through the nose or, occasionally, through the mouth. Although the air flows merge into the oropharynx toward the larynx, trachea, and lungs, it is important to distinguish the functional differences between the nasal and the oral passages, as they determine a different quality and safety of the breath [54].

\subsection{The Nasal Cavity}

The nasal architecture is composed of bony, cartilaginous, and soft matter units (skin/mucosa, muscles, fibroadipose tissue, vessels, nerves), building the external nose and the nasal cavity (Figure 2). Anteriorly to posteriorly, the nasal passage starts from the 
nostrils and the nasal vestibule (interior structures of the external nose) and opens to the nasal cavity. The nasal septum ("inner wall") divides the nose and the nasal cavity medially into two symmetrical departments. From the bottom up, the nasal cavity expands from the hard palate ("floor") to the cribriform plate ("roof"), whereas axially, three conchae (nasal turbinal) differentiate the inferior, middle, and superior zones (meatus). The total length of the nasal passage in adults is estimated at an average of $14 \mathrm{~cm}$, and the total surface area at $160 \mathrm{~cm}^{2}$. Orifices on the lateral wall of the nasal cavity allow the drainage of the paranasal sinuses (frontal, ethmoid, maxillary, and sphenoid) and the connection to the Eustachian tube and nasolacrimal channel $[55,56]$.

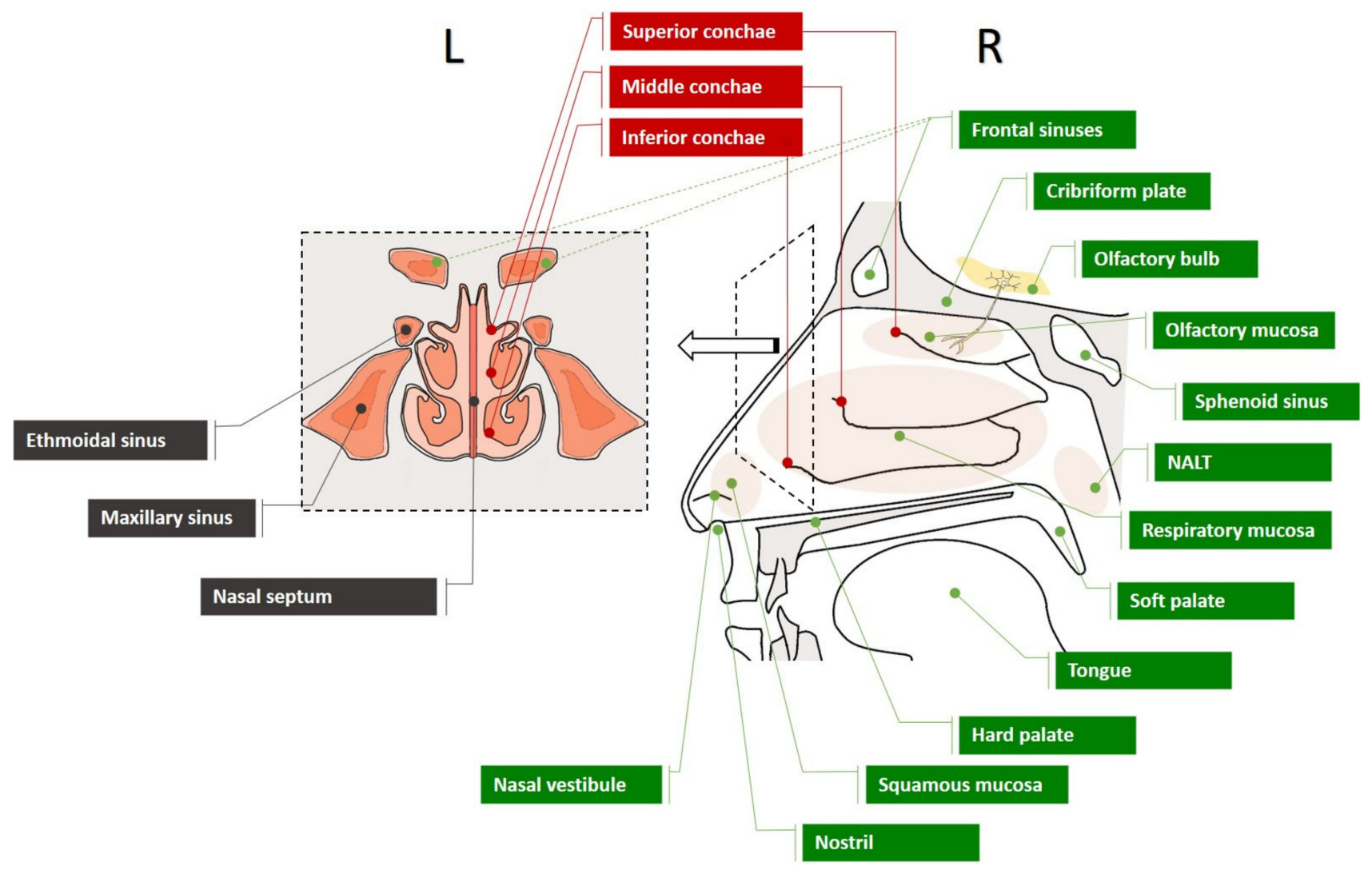

Figure 2. Structure of the nasal cavity: lateral (R) and frontal view (L).

The external nose is covered by skin, which, in the zone of the nostrils and the nasal vestibule, is enriched in hair follicles, giving the growth of the nasal hair (vibrissae) [55]. The latter is responsible for the filtration of larger particles, such as pollen, bacteria, and dust [57]. The finer purification of the inspired air, however, is a function of the respiratory mucosa-the dominant outermost layer of the respiratory compartments, including the nasal cavity. It has a specific structure that allows the secretion and formation of the protective, covering nasal mucus and its motion toward the throat so that the potentially hazardous small particles in the breath, including those that are pathogen-containing, are swallowed instead of inhaled. This process is known as nasal mucociliary clearance and is a part of the overall mucociliary clearance of the respiratory system [26]. It is considered to effectively eliminate $95 \%$ of the particles larger than $15 \mu \mathrm{m}$ in diameter [58]. However, a high percentage of the virus-containing droplets generated through talking, coughing, or sneezing reduce their size substantially due to evaporation (and become airborne) prior to their inhalation from the recipient $[59,60]$. Such particles are in the respiratory range and are less likely to be defeated by the nasal mucociliary clearance; thus, they may remain a threat to the immune system. 


\subsection{The Nasal Mucosa}

The structural and functional features of the nasal mucosa are the key to understanding the physiological nasal defense mechanisms and lay the fundamentals of the biopharmaceutical concept for nasal drug delivery. A region of squamous epithelium follows the lining of haired skin in the nasal vestibule. Posteriorly, passing through a transitional zone, the tissue turns into respiratory mucosa, which covers most parts of the nasal cavity and, further, the pharynx, larynx, and lower airway [61]. The common structure of the mucous membranes includes an epithelium layer laid on a basement membrane that separates it from the underlying lamina propria-a connective tissue layer, host of vascular and neural plexuses, seromucous glands, and immune cells. The mucosa is supported by a thin muscle layer (muscularis mucosa), after which the submucosal tissue (tela submucosa) begins-a connective tissue that nourishes (serves) the mucosa (also contains glands, nerves, and blood vessels). The nasal respiratory epithelium is distinguished by ciliated cells distributed among an assembly of columnar and goblet cells. The former cell type-ciliated cells-is characterized by an elongated (columnar) body, an apical surface of microvilli (cytoplasmic, fingerlike formations), and up to 300 thin, tubular, and mobile appendices (cilia) striking out up to $5 \mu \mathrm{m}$ of the microvilli bed. The microvilli-type morphology (also intrinsic for the apical surface of nonciliated columnar cells) significantly increases the total surface area of the mucus membrane and prevents it from dehydration, while the cilia ensure the motion of the mucus $[55,56]$. The coordinated movement of the cilia is termed "ciliary beating"-a result of synchronized alternation of effective and recovery ciliary strokes triggered by the ATP-dependent motor protein dynein [62]. The goblet cells execute a secretory function, wherefore they are also referred to as unicellular glands. Their nuclei, being displaced toward the cell base, open space for the storage of mucin-containing granules at the apical side, where their release takes place and contributes to the lubrication of the mucosal surface. The density of goblet cells in the epithelial layer significantly increases during inflammation [55]. In addition to the squamous, transitional, and respiratory mucosa, two other zones are also distinguished in the nasal cavity - the olfactory and the lymphoid regions. The olfactory mucosa differentiates from the respiratory mucosa by several parameters: (1) it contains several other cell types specified to provide its chemoreceptive function (olfactory, supporting, and brush cells); (2) the density of ciliated cells is much lower; (3) the olfactory epithelium does not include goblet cells; (4) the serous glands situated in the lamina propria layer are called Bowman's glands and produce less viscous fluid (compared to the respiratory mucus), which makes it more suitable for cleaning (washing) the sensory zones and dissolving substrates $[55,56]$. The lymphoepithelium (NALT—nasopharynxassociated lymphoid tissue) is the zone with the most significance to the immune response in the nasal cavity, for, in its lamina propria layer, clusters of antigen-responding $\mathrm{M}$ cells are found $[63,64]$. In adults, it is strategically located at the pharyngeal entrance and presented in the structure of the tonsils in the Waldeyer's ring (the palatine, tubal, adenoid, and lingual tonsils) [65].

The nasal cavity is abundantly vascularized, which allows the effective processing of the inspired air to optimal humidity and temperature. The predominant blood supply is ensured by the sphenopalatine artery and the ethmoidal branches of the ophthalmic artery. Blood drainage occurs through the ethmoidal veins to the pterygoid, cavernous, and ophthalmic plexuses. The general innervation of the nasal mucosa derives from branches of the maxillary and ophthalmic nerves, whereas the sensory innervation, relating to the sense of smell, is a function of the olfactory nerves $[55,58]$. The latter enter the nasal cavity through openings in the cribriform plate, innervate the olfactory region (located in the uppermost part of the cavity), and connect to the olfactory bulb in the cranial cavity [66]. Thus, they directly relate the nasal cavity with the brain.

\subsection{The Mucus}

The nasal mucus is a 10-15 $\mu \mathrm{m}$ thick, fluid biophysical barrier covering the nasal mucosa and protecting it from potentially hazardous agents having reached the intralu- 
minal space (substances and pathogens) [58]. It serves as a mobile carrier for entrapped pathogens, particulate matter, and dissolved substrates and is moved by the ciliary beating at an average velocity of 2-25 mm per minute [67]. At the same time, it hosts and mediates the defense action of immunoglobulins (IgA and $\operatorname{IgG}$ ) [68,69], immune cells (neutrophils, monocytes, macrophages), nitric oxide (NO), enzymes (lysozyme), proteins (lactoferrin), and the protective microflora-all produced and/or present in the nasal mucosa and responsible for its specific or nonspecific immune response [58]. The liquid milieu of the mucus is provided predominantly by the exocrine seromucous glands and, to a lesser extent, by the plasma transudation and the tear fluid [58,61]. However, the viscoelastic structure of the nasal mucus is defined by the presence of mucins (MUC) - glycoproteins, synthesized and secreted by the goblet cells [55]. Several types of mucins are identified in the nasal fluid-MUC5AC and MUC5B, which are cross-linked and gel-forming mucins, and MUC1 and MUC4, which are cell-surface mucins. Their distinct distribution determines a two-phase state of the nasal mucus. The first, lower phase (pericilliary layer) is characterized by low viscosity and lubricates the microvilli. It contains the cell-surface mucins, which are dominant glycocalyx constituents, and separates the pericilliary layer from the upper-laying viscous fluid. The latter is considered a second phase of the nasal mucus, in which the oligomerizing and network-forming MUC5AC and MUC5B design a gel-like structure $[8,26]$. The mucins possess a highly reactive structure, which can bind to various substrates, including microbial adhesins, drugs, and macromolecules, via hydrogen bonding, disulfide bridges, Van der Waals attraction, or other mechanisms. The presence of sialic acids and sulfated groups in the saccharide parts of the mucins provides a negative charge and slightly acid physiological $\mathrm{pH}$ (5.5-6.5) of the nasal mucus [58]. The volume and viscosity of the mucus are regulated by macro- and microenvironmental factors and influenced by the presence of inflammatory processes, microbial infections, irritants, and other [55].

\subsection{The Role of the Oral Cavity as a Portal of Entry for Respiratory Pathogens}

The oral cavity may become an entry point for respiratory pathogens through the orallung axis, oromucosal infection and/or absorption, or even the oral-gut axis [70-73]. The former mechanism relates to the act of oral inhalation (mouth breathing) or microaspiration, by which a respiratory pathogen bypasses the antigen-resilient nasopharyngeal zone and reaches the lower airways [74,75]. For most people, occasional mouth breathing (partial-combined or alternating with nasal breathing, or absolute) is inevitable during physical exercise, sleeping, singing, talking, etc. [76]. In contrast, habitual mouth breathing (due to obstructive nasal pathologies, such as allergic rhinitis, recurrent infections, and deviated septum [77]) is defined as an abnormal respiratory pattern [78]. Indeed, for healthy individuals, wearing a face mask is one prerequisite for sporadic mouth breathing, resulting from the intention to compensate the airflow. The oral inspiration is considered riskier for respiratory infections since the breath is devoid of several defense mechanisms inherent for the nasal air processing; these include control over the airflow, filtration, humidification, and antimicrobial processing through reactive species produced in the nasal cavity (e.g., nitric oxide-NO) [79]. The antimicrobial activity of NO has been highlighted by many scientists recently, confirming the importance of nasal breathing for the host's natural defense capacity against SARS-CoV-2 infection [80-82].

Oral pathogen entry could also be observed via oromucosal or gastro-intestinal infection and absorption. The oral cavity possesses, adjusted to its physiological designation, high enzymatic activity, diverse microbiota, mechanically sustainable stratified mucosal epithelium, salivary clearance, and a mucosal-associated lymphoid tissue region (MALT) [83,84]. Yet, these barriers are not absolute and, under certain circumstances (impaired integrity of the mucosa, nutritional and other habits, accompanying disease, compromised microflora, etc.), the oral mucosa can serve as a site of adherence and absorption for respiratory pathogens [85]. One eloquent example could be given again for the novel Coronavirus, which is currently reported to adhere to and infect salivary glands cells and 
oromucosal epithelial cells, especially in the tongue and gingival area (a mechanism related to the commonly observed loss-of-taste symptom of COVID-19 infection). This fact is explained by the high density of the SARS-CoV-2 entry factors in the oral tissues in question, i.e., the ACE2 receptor and the transmembrane serine proteases 2 (TMPRSS2) [70,71,86-88]. Furthermore, although a respiratory virus by definition, the SARS-CoV-2 is described to infect the intestinal enterocytes (also expressing the coronaviral cell entry factors) through the oral-gut axis and systemically spread through the gut-lung axis [89-92]. The risk of such a form of infection is increased under the conditions of lowered stomach acidity (above pH 3, where the virus survival rate is higher) [93,94]. Similar findings are reported for MERS-CoV [95]. In addition to the risk of primary infection through the oral structures, oral hygiene and immunity are crucial for the prevention of co-infection, which can arise in the same aforementioned manners [75,96].

\section{Prevention and Prophylaxis of RTI's}

The prevention of infectious diseases is a priority mission of the healthcare system, insured by a complex algorithm of actions focused on limiting the spread and morbidity. The public health measures include recommendations for effective personal hygiene, the imposition of behavioral norms in a social environment (the adherence to a social distance, the wear of a mask, the abstinence from social contacts in case of symptomatic discomfort, quarantine, etc.), regular screening and testing, and other [97-99]. Although all individuals benefit from an effectively maintained epidemiological situation, most often, they are not the subject of protection; the community is. How successful the preventive measures of this kind will be for an individual depends on many factors, including their own understanding and compliance. In the light of the ongoing COVID-19 pandemic, the misuse of protective supplies, such as face masks, is one eloquent example for the above. Many research studies emphasize the necessity of correct and consistent application of the facecovering masks in order for them to significantly decrease the risk of infection $[100,101]$. However, the proper implementation of this measure has been long proven to suffer from a low compliance among the population [102]. Furthermore, particular materials possess a reduced capacity to effectively filtrate bacteria and virus-containing particles from inspired/expired air [103-106]. Last but not least, circumstantial or associated with the incorrect use, insufficient efficacy of masks and even increased risk of infection are being reported [107-112].

Prophylaxis is an integral part of prevention with much higher significance to personal health. It consists of actions taken to provide protective treatment for a specific disease or a group of diseases and is often strictly related to the pathogenesis [113]. In the context of respiratory infections, pre- and post-exposure to pathogen prophylactic measures are to be distinguished. In fact, some of the methods of prophylaxis are effective in both phases. Prophylactic treatment is carried out after a physician's prescription or recommendation or as a result of patients' self-awareness when it concerns the use of well-known and over-the-counter products. Two major branches of the prophylactic treatment of respiratory infections are immunoprophylaxis and chemoprophylaxis. The former method refers to the administration of vaccines, serums, or immunoglobulins, whereas the latter describes the application of chemotherapeutic agents for the aim of prevention. The most significant and relevant prophylaxis treatment methods (approved or in a research phase) for RTIs will be discussed.

\subsection{Immunoprophylaxis}

Immunoprophylaxis is, indisputably, the most effective preventive step to be taken in the name of limiting the morbidity and mortality due to RTIs. Vaccination, also known as active immunization, is an available option against $S$. pneumoniae, $H$. influenzae (type b), and Influenza, and recently, against the novel Coronavirus-SARS-CoV-2. Several technologies are recognized in vaccine development. They include the use of the whole pathogen (live-attenuated and inactivated vaccines), viral and bacterial vectors, nucleic acid antigens 
(mRNA and DNA vaccines), subunits (e.g., purified protein or recombinant protein vaccines), polysaccharide-protein conjugates, toxoids, virus-like particles, outer membrane vesicles, and antigen-presenting cells [114]. The main setbacks of vaccination are related to the pathogen variability, short-term immune response, or low efficacy [115]. Furthermore, it is not the "first choice" preventive measure for immunocompromised or chronically ill patients [116]. The mucosal vaccination, in this regard, offers some advantages, as it allows antigen-specific local, as well as systemic, immune response stimulation through a nonparenteral route of administration (such as intranasal and oral) [117]. Passive immunization, on the other hand, is an alternative to vaccination by administration of antibody preparations (polyclonal antibodies-containing serums or monoclonal antibodies) $[118,119]$. The passive immunoprophylaxis is characterized by a much lower risk of side effects, compared to the vaccine administration, and faster onset of activity, which is highly valuable for hospitalized patients in a post-exposure stage [115,119,120]; however, a passively acquired immunity lasts for a shorter time and requires a continuous supply of the immune preparation $[115,119]$. An interesting branch of passive immunoprophylaxis, with practical significance in the prevention of RTIs, is the administration of immunoglobulin $\mathrm{Y}(\mathrm{Ig} Y)$. The is derived from the egg yolks of birds immunized with specific antigens and represents a functional analog of the mammalian immunoglobulin G (IgG) [121]. IgY immunotherapy distinguishes with numerous advantages over conventional antibody preparations-high tolerability and safety [115,119], longer circulating half-life and greater potential for antigen binding (compared to IgG) [122], ecologically and animal-friendly technology of production [115,123], and lower production costs (compared to those for monoclonal antibodies) [119]. So far, the efficacy of IgY immunotherapy has been proven for the prevention of Influenza [115,119], Pseudomonas aeruginosa [124], Mycobacterium tuberculosis [125], bovine RSV [126], SARS-CoV [127], and SARS-CoV-2 [128] infections, and other pulmonary diseases.

\subsection{Chemoprophylaxis}

The term chemoprophylaxis relates to the preventive administration of antimicrobial agents in the pre- or post-exposure stage $[129,130]$. Key targets for the drug action are the pathogens themselves (inhibition of adhesion, entry, replication) or the host cell factors [131].

Long established in clinical practice is the prophylactic use of antibiotics and, less frequently, of antiviral agents $[132,133]$. Despite the great health benefits of prophylactic antibiotic treatment, especially among hospitalized and immunocompromised patients [134-136], it remains a leading cause of the major and global problem of antibiotic resistance $[137,138]$. The administration of some antiviral drug representatives with neuraminidase inhibitory mechanism of action (Oseltamivir, Zanamivir) is approved for the prophylactic treatment of Influenza [116]. However, their use is more relevant for patients at high risk than for healthy adults due to the substantial side effects and the often unfavorable risk-benefit ratio [139]. At present, therapy with Bamlanivimab $700 \mathrm{mg}+$ Etesevimab $1400 \mathrm{mg}$ (intravenous infusion) or Casirivimab $600 \mathrm{mg}+$ Imdevimab $600 \mathrm{mg}$ (subcutaneous injections or intravenous infusion) is the current World Health Organization's recommendation for post-exposure prophylaxis of Coronavirus (SARS-CoV-2). In contrast, no drug has been officially recommended for pre-exposure prophylaxis [140]. Under investigation in clinical trials are the efficacy and safety of several agents in pre- or post-exposure stage, including Tenofovir and Emtricitabine (separately or in combination), Hydroxychloroquine, Ivermectin, and interferons [140,141]. Furthermore, the benefits of supplements such as zinc, vitamin $C$, and vitamin D are also under continuous research, despite their long-standing use and known efficacy in prophylaxis of other RTIs [140].

Active substances or preparations of natural origin (herbal, animal, fungal, bacterial, yeast) are widely studied and used for prophylaxis of RTIs. Their application in medicinal products is preferred and prioritized due to the higher safety profile and increased patient compliance. The antimicrobial (and especially antiviral) activity of natural components is a 
trendy subject of research and is leading to the accumulation of more and more scientifically based facts to support the pharmaceutical development of natural products for RTI prophylaxis [142-144]. Unlike most synthetic drugs, bioactive compounds (BACs) often possess a complex mechanism of action, determining a broad spectrum of activity and efficacy in different stages of the infectious disease [141,145]. Some biomolecules (primary or secondary metabolites), including polysaccharides, glycoproteins, flavonoids, and other phenolic compounds, alkaloids, and terpenoids, are recognized for their ability to competitively bind to the host cell receptors or the viral adhesins in an antibody-like pattern and prevent the receptor-determined cell entry of the pathogenic microorganisms [14,142-144]. This fact is to be explained with a structural similarity of many BACs with segments of the targeted host receptors and adhesins [142] and/or high reactivity (e.g., high hydrogen bond donor and acceptor number [144], chelating ability). More than 90 natural compounds of the above-mentioned phytochemical categories have shown anti-coronavirus activity [142]. The latest studies and reviews focus the attention on S-containing polysaccharides (Chitosan [146] and semisynthetic derivatives [147], kappa-, iota-, lambda-Carrageenan [148-150], Fucoidan [150-152]), Lactoferrin [153,154], Aloe vera polysaccharides [155], the flavonoids Hesperidin [14,156,157], Hispidulin [158], Quercetin [153], Rutin [159], Resveratrol [160], the saponin Glycyrrhizin [161], and the diterpenoid Andrographolide [162,163]. Many of them possess not only the ability to block the adhesin-receptor connection and following viral entry, but are also proven to exhibit antiviral activity due to inhibition of viral replication (Chitosan and other sulfated polysaccharides [145,164,165], Resveratrol [166,167], Aloe vera polysaccharides [155], Glycyrrhizin [168], Andrographolide [169]), inhibition of protein synthesis (Aloe vera polysaccharides [155] and Andrographolide [169]), blocking the viral release and spread (Andrographolide [169]), and/or immunomodulatory properties (Chitosan [170]). The antiviral potency of other biomolecules is primarily due to interference in one or multiple steps of the infectious cycle of pathogens (i.e., after adhesion) and by activating the host immunomodulatory system. Examples are Echinacea spp. phenolic glycosides and alkamides (immunomodulatory effects on macrophages and NK cells [144,171]), Astragalus spp. polysaccharides (inhibition of viral replication, and immunomodulatory effects on macrophages and NK cells [172,173]), Rhodiola rosea flavonoids (inhibition of viral replication and immunity enhancement [174]), and alginate (immunity enhancement [175]). Not by accident, some of the polysaccharides above (Chitosan, Astragalus spp. polysaccharides, Carrageenan, and Alginate) are proposed by many authors as potent vaccine adjuvants to improve immune response [170,176-180].

Probiotic supplementation is another strategy based on natural preparations worth mentioning in RTI prophylaxis. The beneficial effect of probiotic strains on the duration and severity of RTIs, including Rhinovirus, Influenza, RSV, and S. pneumoniae infections, has been long studied and established [181-183]. It is owed to several mechanisms, among which the most important are (1) immunomodulation-probiotic bacteria comprising immunostimulatory constituents such as peptidoglycan, lipoteichoic acid, Toll-like receptor ligands, and muramyl dipeptide; their use leads to an increase in the level of type I interferons, the number and activity of natural killer (NK) cells, T cells, and IgA-expressing B cells in the colon and lymph nodes, and the level of specific antibodies in the lungs [184,185]; (2) production of antimicrobial substances (lactic acid, hydrogen peroxide, and bacteriocins) [185]; (3) competitive adhesion of probiotic bacteria on the sites of potential colonization of pathogenic bacteria [186], and (4) interaction with receptors, binding domains, and suppression of toxin-mediated responses [186]. An interesting finding of Verma et al. on Lactobacillus paracasei strains suggests a potential anti-SARS-CoV-2 activity [187]. The team reveals the expression of human ACE2 in the probiotic bacteria in question, which could prevent the viral cell entry by interaction with the S-protein of the virus $[185,187]$.

As the implementation of nanotechnologies is an integral part of contemporary and innovative science, many nanotechnology-based attempts are being made to improve the pharmacological and biopharmaceutical properties of effective active ingredients in RTI prophylaxis. Nanomaterials find their application in the production of safety supplies 
(e.g., nanofibrous materials for the production of protective clothing, face masks and filters, enriched or not with antimicrobial agents [188-190]), in the composition of targeted and sustained drug delivery forms (e.g., cellular nanosponges from plasma membranes of human lung epithelial type II cells or human macrophages, containing protein receptors to bind and neutralize SARS-CoV-2 [191]; poly(lactide-co-glycolide)-b-poly-(ethylene glycol)maleimide polymeric Ivermectin-loaded nanoparticles for sustained drug delivery [192]), and in gene delivery (e.g., lipid nanoparticles as vehicles for targeted intracellular delivery of mRNA $[193,194]$ - a technology used in some SARS-CoV-2 vaccines).

The mechanisms of action of the various therapeutics-synthetic or natural, included or not in nano-carriers-suggest that they could be potentially effective in RTI prophylaxis if not only systemically but also nasally or oromucosally applied. The anatomo-physiological peculiarities of the upper respiratory tract and the biopharmaceutical characteristics of the nasal and oromucosal route for drug delivery are in tight relationship with the choice of a dosage form and active ingredient and the possible beneficial result for the local protection against respiratory infections.

\section{The Nasal and Oromucosal Drug Delivery}

Nasal and oromucosal drug delivery is a contemporary field of research, mostly because of the multiple advantages they offer beyond their most commercial designationto treat and/or protect the mucosa. The nasal route stands out as one of the most prospective sites for peptide and protein delivery [195], and direct brain drug delivery (via the olfactory bulb) $[196,197]$; the buccal route reveals opportunities for sustained drug delivery, and the sublingual route allows fast access to the systemic circulation [198,199]; both the nasal and the oromucosal routes are eligible for mucosal vaccination, for which target zones are the lymphoid regions (NALT and MALT, respectively) [65,200-203]. However, in the light of the current topic, the focus will be directed to nasal and oromucosal drug administration for local protection.

A protective mucosal formulation might be designed to strengthen the biophysical barrier properties of the mucus and be suitable for reconstructive aims, exert a local pharmacological activity, and/or disinfect. In general, the formation of a stable, even, and retentive film on the mucus membrane is required, with the capacity to ensure an adequate drug diffusion to the target structures (if the formulation is drug-loaded) while not interfering with the physiological functions at the site of application (e.g., inhalation, mucociliary clearance, smell, chewing, swallowing, and talking). Exceptions are the rinsing solutions and the mucosal vaccines, as the former are not intended to adhere, whereas the latter are intended to fully cover the mucosal surface (they are designated to be delivered to specific zones in the cavities).

\subsection{Mucoadhesion-Principles and Utilization in Mucosal Dosage Forms}

Mucoadhesion is the phenomenon defined by the sustainable adhesive attraction between a mucosal surface and a second biological or synthetic (most often polymeric) substrate. The utilization of mucoadhesive excipients is an integral part of the design of mucosal dosage forms since they ensure a prolonged retention, intimate contact with the mucosa, and resilience of the emerging film to gravity and unfavorable physiological processes at the site of application (such as the nasal mucociliary clearance and the great oscillatory stress in the oral cavity) $[13,204]$. Mucoadhesive properties are inherent for many polymeric materials of natural and semisynthetic origin that possess the ability to interact with the mucus mucins, the mucus milieu, and/or the mucosal epithelia in their hydrated state. The class of mucoadhesive polymers is heterogeneous and diverse; it includes polysaccharides (e.g., natural gums-Xanthan, Guar, Carob; Chitosan, Carrageenan, Sodium Alginate, Hyaluronic Acid, and derivatives), acrylic/ methacrylic polymers (e.g., Carbomer and Polycarbophil), cellulose derivatives (Hydroxypropylmethyl cellulose, Hydroxyethyl cellulose, Hydroxypropyl cellulose, Carboxymethyl cellulose (sodium)), and many other (e.g., Poly(Ethylene Oxide), Poly(Vinyl) Alcohol, Poly(Vinyl) Pyrrolidone) [205]. A mucoadhesive 
connection may be owed to physical phenomena (e.g., hydrogen bonds, van der Waals forces, hydrophobic interactions), physico-chemical events (e.g., wetting, swelling, and dissolution of the mucoadhesive polymers, diffusion, and adsorption of the polymer chains into the mucus matrix and intercellular space of the mucus membrane), and/or specific or nonspecific chemical interactions (e.g., ionic or covalent bonds, including disulfide bonds and intermolecular cross-linking) [205,206]. The nature of the occurring interactions is determinative for the strength of adhesion. For example, thiomers (thiolated polymers, e.g., thiolated Chitosan, Alginate, Poly (Acrylic Acid)) are among the most potent mucoadhesives due to their capability to covalently bind to the cysteine-rich mucins through disulfide bridges [207-209]. Other important structural peculiarities of a mucoadhesive polymer are the presence and prevalence of amino, hydroxyl, and carboxyl groups, which get engaged in hydrogen bonding with mucins and cell-surface molecules [209-211]; the degree of intramolecular cross-linking and hydrophilic-lipophilic properties, which should be balanced (or optimized) with a view of sufficient molecular flexibility, but satisfactory sustainability of the applied protective/drug-delivery layer at the same time; the charge density, as it correlates to stronger adhesion (anionic and cationic polymers bind more efficiently than neutral ones do); the molecular mass, as usually, longer polymer chains contribute to better penetration and contact with the mucus and the underlying mucosal epithelium. The concentration of the mucoadhesive polymer in the pharmaceutical formulation, the natural lubrication of the mucosa, and $\mathrm{pH}$ also affect the mucoadhesion efficacy $[205,206]$.

\subsection{Nasal Dosage Forms}

The nasal dosage forms include drops and liquid sprays, powders, rinses, semisolid preparations (gels, creams, or ointments), and sticks [212]. With the exception of the latter two groups, all the other forms are eligible for the aims of local protection of the nasal mucosa.

The nasal drops have the advantage of being well-tolerated and not "aggressive" to the mucosa, but upon the standard recommendations for administration, they reach and deposit on the posterior nasal cavity. Because of the higher cilia density and the greater permeability of the posterior mucosal site, they stimulate fast mucociliary clearance and drug absorption and are only preferred when a quick onset of pharmacological action is needed. Contrariwise, the nasal sprays ensure a distribution at the anterior nose and further spread and coverage of the posterior parts due to the mucociliary clearance $[213,214]$. Therefore, they are recognized as the better choice for delivering and retaining nasal liquids for protective purposes. However, the atomization pattern, and thus the type of nozzle and pump in the spray device, is of great importance for the spreading and localization of the applied dose [215,216].

The nasal powders offer an alternative to liquid forms with greater physicochemical and microbiological stability, prolonged retention, and drug absorption. Furthermore, they allow the administration of larger doses and do not set a requirement for solubility of the drugs and excipients. However, these solid nasal forms are still not widely introduced to the pharmaceutical market due to the higher production costs, lower mucosal tolerability, and patient compliance [217].

The nasal rinses are intended to be administrated in larger volumes, and wash and clear the nasal cavity from potentially hazardous agents. Most often, they are isotonic solutions enriched or not with antiseptics [212].

Regardless of the type of dosage form, the most significant challenges to the protective nasal formulations are the fast mucociliary clearance and the potential ciliotoxicity of particular constituents [212]. Although mucoadhesive polymers and viscosity enhancers are known to oppose the natural clearance mechanisms in the nasal cavity, quite often, the principles of their action contradict the provision of other desired qualities. The sustainability (mechanical strength) of a mucosally applied film, for example, increases in the presence of poor water-soluble polymers (with greater hydrophobicity or high degree of cross-linking), whereas such polymers indeed lower the mucoadhesive capacity [204]. 
The higher concentration of mucoadhesive polymers and the greater viscosity and yield stress of the formulation normally favor endurable retention and stability of the mucoadhesive layer but violate sprayability and spreadability [218,219]. The elaboration of in situ gelling systems, in this regard, is an irreplaceable tool. The systems in question ensure an adopted temperature-, ion-, or pH-dependent sol-gel transition of the formulation after application $[220,221]$. Commonly used polymers in nasal forms for that purpose are the Poloxamers (poly(ethylene oxide)/poly(propylene oxide) copolymers), Gellan gum, Carbomer, and others [220-223]. As so many requirements are to be met, the protective nasal dosage forms formulation often relies on the combination of different polymers, each contributing to or balancing certain features [15]. Within the choice of excipients, it is not to be forgotten that some polymers, especially those of natural origin, exhibit antiviral and antibacterial properties themselves [224]; thus, they would be highly preferable multifunctional constituents of a protective nasal formulation.

Ciliotoxicity is defined as the ability of particular substances to disrupt the regular ciliary beating frequency and, therefore, negatively affect the natural nasal ciliary clearance. Cilitoxic properties are known for most preservatives, "xerogel"-forming cellulose polymers, local anesthetics, corticosteroids, and antibiotics. The effects may vary from temporary and reversible to irreversible and inhibitory. In order to diminish the possible ciliotoxicity of a nasal preparation, the use of buffers ( $\mathrm{pH} 6-8)$, tonicity-adjusting agents, and humectants is recommended [212,225].

The drug absorption pathways in the nasal cavity are not a primary concern when it comes to the development of a locally active formulation. However, for drug-containing formulas, they still need to be taken into account in order to predict or prevent an undesired systemic intake. Because of the rich blood supply and lymph drainage in the nasal area, therapeutic molecules responding to certain physico-chemical criteria may reach the systemic blood circulation and induce a systemic response. The olfactory region is a particularly critical zone, where a molecular or even particulate uptake may occur through the olfactory nerves to the brain; such uptake is even possible for pathogenic microorganisms [226-228]. Therefore, the risk of microbial contamination of nasal pharmaceutical formulations should be addressed and eliminated.

\subsection{Oromucosal Dosage Forms}

The oromucosal dosage forms are diverse preparations intended to be applied in the oral cavity and exert local or systemic effects. Convenient for protective purposes are easily spreadable forms, such as oral rinse solutions, gargles, sprays, lozenges, and pastilles [17,229-232]. Most commonly, they target the oropharyngeal and/or the buccal mucosa and contain wide-spectrum antiseptics and antimicrobial agents designated to disinfect the oral cavity. Undesired systemic drug intake across the highly vascularized buccal mucosa is possible for drugs with good permeability [199].

Unexceptionally, the oromucosal forms may contain mucoadhesive polymers to retain and build a protective barrier against irritants and pathogens or cover infection-susceptible lesions. However, the typically high levels of oscillatory stress in the oral cavity throughout the daily routine of chewing, drinking, swallowing, talking, etc., and the significant salivary flow (at approximately 1-2 $\mathrm{mL} / \mathrm{min}$ [233]), limit the time of retention and determine the necessity of frequent application. As an alternative, buccal gel-forming tablets and buccal films, although predominantly used as modified-release drug delivery systems for systemic absorption, could also be applied for local protection [234,235].

Table 1 summarizes data from the latest studies on nasally and/or orally active therapeutics in RTI prophylaxis, relevant to SARS-CoV-2 infection prevention. The list includes new and repurposed drugs, formulations, and marketed products, scientifically proven for their efficacy against SARS-CoV-2. 
Table 1. List of nasally and/or oromucosally administrated therapeutics for SARS-CoV-2 prophylaxis.

\begin{tabular}{|c|c|c|c|c|c|c|}
\hline Active Agent & $\begin{array}{c}\text { Form of } \\
\text { Application }\end{array}$ & $\begin{array}{l}\text { Type of Studies } \\
\text { Conducted/in } \\
\text { Progress }\end{array}$ & Efficacy & Mechanism of Action & $\begin{array}{l}\text { Available Marketed } \\
\text { Product(s) }\end{array}$ & References \\
\hline \multicolumn{7}{|c|}{ ANTIGEN-SPECIFIC PROPHYLAXIS } \\
\hline $\begin{array}{c}\text { Adenovirus- } \\
\text { vectored vaccine } \\
\text { encoding the spike } \\
\text { (S)-protein/RBD } \\
\text { domain of } \\
\text { SARS-CoV-2 }\end{array}$ & Intranasal & $\begin{array}{ll}\text { - } & \text { In vivo } \\
\text { - } & \text { preclinical } \\
\text { Clinical trials }\end{array}$ & SARS-CoV-2 & $\begin{array}{l}\text { Induction of S-specific } \\
\text { and receptor binding } \\
\text { domain (RBD)-specific } \\
\text { serum and secretory } \\
\text { antibodies (IgG and IgA, } \\
\text { respectively), and } \\
\text { lung-resident T cells }\end{array}$ & $\mathrm{n} / \mathrm{a}^{\mathrm{a}}$ & [236-242] \\
\hline $\begin{array}{l}\text { Genetically } \\
\text { modified } \\
\text { live-attenuated } \\
\text { vaccines }\end{array}$ & Intranasal & $\begin{array}{ll}\text { - } & \text { In vivo } \\
\text { preclinical } \\
\text { - } \quad \text { Clinical trial }\end{array}$ & SARS-CoV-2 & $\begin{array}{l}\text { Induction of S-specific } \\
\text { and receptor binding } \\
\text { domain (RBD)-specific } \\
\text { secretory antibodies } \\
\text { (IgA) }\end{array}$ & $\mathrm{n} / \mathrm{a}$ & [243-245] \\
\hline $\begin{array}{l}\text { S-protein embedded } \\
\text { bacterial outer } \\
\text { membrane vesicles }\end{array}$ & Intranasal & $\begin{array}{l}\text { - In vivo } \\
\text { preclinical }\end{array}$ & SARS-CoV-2 & $\begin{array}{c}\text { Induction of } \\
\text { SARS-CoV-2-specific } \\
\text { neutralizing antibodies }\end{array}$ & $\mathrm{n} / \mathrm{a}$ & [246] \\
\hline $\begin{array}{l}\text { Monoclonal IgM } \\
\text { antibodies }\end{array}$ & Intranasal & $\begin{array}{l}\text { In vivo } \\
\text { preclinical }\end{array}$ & SARS-CoV-2 & $\begin{array}{l}\text { Antigen-specific binding } \\
\text { to SARS-CoV-2 } \\
\text { RBD domain }\end{array}$ & $\mathrm{n} / \mathrm{a}$ & {$[247,248]$} \\
\hline $\begin{array}{l}\text { Monoclonal IgG } \\
\text { antibodies }\end{array}$ & Nasal spray & $\begin{array}{l}\text { - } \quad \text { In vivo } \\
\text { preclinical }\end{array}$ & SARS-CoV-2 & $\begin{array}{l}\text { Antigen-specific binding } \\
\text { to SARS-CoV-2 } \\
\text { RBD domain }\end{array}$ & $\begin{array}{l}\text { InvisiMask }^{\mathrm{TM}} \text { (Eureka } \\
\text { Therapeutics, USA) }\end{array}$ & {$[249,250]$} \\
\hline \multicolumn{7}{|c|}{ II. $\quad$ BROAD-SPECTRUM ANTISEPTICS } \\
\hline \multirow{4}{*}{$\begin{array}{l}\text { Povidone-iodine } \\
\quad \text { (PVP-I) }\end{array}$} & Oral rinse & \multirow{2}{*}{$\begin{array}{ll}- & \text { In vitro } \\
- & \text { Clinical trials }\end{array}$} & \multirow{4}{*}{$\begin{array}{l}\text { Broad-spectrum } \\
\text { antimicrobial } \\
\text { activity, including } \\
\text { against SARS-CoV, } \\
\text { MERS, and } \\
\text { SARS-CoV-2 }\end{array}$} & \multirow{4}{*}{$\begin{array}{l}\text { Oxidation-determined } \\
\text { damaging on microbial } \\
\text { nucleic acids, proteins, } \\
\text { and cell membranes }\end{array}$} & $\begin{array}{c}\text { Betadine }^{\circledR} 1 \% \text { (Avrio } \\
\text { Health L.P. Purdue } \\
\text { Pharma Inc., USA), } \\
\text { Halodine }{ }^{\circledR} 1.7 \% \\
\text { (Halodine LLC, USA) }\end{array}$ & \multirow{4}{*}[230,251-260]{} \\
\hline & $\begin{array}{l}\text { Gargling } \\
\text { solution }\end{array}$ & & & & $\begin{array}{c}\text { Betadine }^{\circledR} \text { gargle 0.5\% } \\
\text { (Avrio Health L.P. } \\
\text { Pur-due Pharma Inc., } \\
\text { USA) }\end{array}$ & \\
\hline & $\begin{array}{c}\text { Oral and } \\
\text { nasal spray }\end{array}$ & - $\quad$ Clinical trials & & & $\mathrm{n} / \mathrm{a}$ & \\
\hline & $\begin{array}{c}\text { Nasal } \\
\text { irrigation }\end{array}$ & - $\quad$ Clinical trial & & & $\mathrm{n} / \mathrm{a}$ & \\
\hline $\begin{array}{l}\text { Chlorine dioxide } \\
\text { (stabilized) }\end{array}$ & Oral rinse & In vitro & $\begin{array}{l}\text { Broad-spectrum } \\
\text { antimicrobial } \\
\text { activity, including } \\
\text { against HCoV-229E, } \\
\text { Influenza A, } \\
\text { SARS-CoV, and } \\
\text { SARS-CoV-2 }\end{array}$ & $\begin{array}{l}\text { Oxidation-determined } \\
\text { damaging on microbial } \\
\text { nucleic acids, proteins, } \\
\text { and cell membranes }\end{array}$ & $\begin{array}{c}\text { ClōSYS }^{\circledR} \text { oral care } \\
\text { products (Rowpar } \\
\text { Pharmaceuticals, Inc., } \\
\text { USA) }\end{array}$ & {$[231,261]$} \\
\hline $\begin{array}{l}\text { Hypochlorous acid } \\
\text { (HCLO) }\end{array}$ & $\begin{array}{l}\text { Nasal and oral } \\
\text { spray }\end{array}$ & $\begin{array}{ll}-\quad & \text { In vitro } \\
- & \text { Clinical trial }\end{array}$ & $\begin{array}{l}\text { Broad-spectrum } \\
\text { antibacterial } \\
\text { activity, including } \\
\text { against SARS-CoV-2 }\end{array}$ & $\begin{array}{l}\text { Oxidation-determined } \\
\text { damaging on viral } \\
\text { genome }\end{array}$ & $\begin{array}{c}\mathrm{n} / \mathrm{a} \\
\text { Tehclo }^{\mathrm{TM}} \text { technology } \\
\text { platform (APR } \\
\text { Nanotechnologies SA, } \\
\text { Switzerland) for } \\
\text { delivery of } \\
\text { HCLO-Acid-Oxidizing } \\
\text { Solution (AOS2020) } \\
\text { is used, }\end{array}$ & {$[262,263]$} \\
\hline
\end{tabular}


Table 1. Cont.

\begin{tabular}{|c|c|c|c|c|c|c|}
\hline Active Agent & $\begin{array}{c}\text { Form of } \\
\text { Application }\end{array}$ & $\begin{array}{l}\text { Type of Studies } \\
\text { Conducted/in } \\
\text { Progress }\end{array}$ & Efficacy & Mechanism of Action & $\begin{array}{l}\text { Available Marketed } \\
\text { Product(s) }\end{array}$ & References \\
\hline \multicolumn{7}{|c|}{ POLYMERIC ANTIMICROBIAL AGENTS } \\
\hline $\begin{array}{l}\text { Hydroxypropyl } \\
\text { methyl cellulose }\end{array}$ & $\begin{array}{l}\text { Nasal spray, } \\
\text { Nasal powder } \\
\text { spray }\end{array}$ & $\begin{array}{ll}- & \text { In vitro } \\
\text { - } & \text { In vivo, on } \\
\text { human } \\
\text { volunteers }\end{array}$ & $\begin{array}{l}\text { Nonspecific } \\
\text { mucosal protection } \\
\text { against respiratory- } \\
\text { transmitted } \\
\text { pathogens }\end{array}$ & $\begin{array}{l}\text { Formation of a physical } \\
\text { barrier on mucosa to } \\
\text { facilitate the process of } \\
\text { pathogen entrapment } \\
\text { and clearance; } \\
\text { additionally, Taffix }{ }^{\mathrm{TM}} \\
\text { (Nasus Pharma Ltd., } \\
\text { Israel) nasal spray } \\
\text { creates an acidic } \\
\text { microenviroment, } \\
\text { unfavorable for most } \\
\text { respiratory pathogens }\end{array}$ & $\begin{array}{l}\text { Taffix } \mathrm{TM} \text { (Nasus Pharma } \\
\text { Ltd., Israel) nasal spray, } \\
\text { Nasaleze nasal spray }\end{array}$ & {$[264,265]$} \\
\hline Astodrimer sodium & Nasal spray & $\begin{array}{ll}- & \text { In vitro } \\
- & \text { In vivo } \\
& \text { preclinical }\end{array}$ & $\begin{array}{l}\text { Broad-spectrum } \\
\text { antiviral activity, } \\
\text { including against } \\
\text { SARS-CoV-2 }\end{array}$ & $\begin{array}{c}\text { Blocking of viral } \\
\text { adhesion and entry by } \\
\text { binding to viral adhesins } \\
\text { and cell entry factors, } \\
\text { such as heparan sulfate } \\
\text { proteoglycans }\end{array}$ & $\begin{array}{l}\text { Viraleze }^{\mathrm{TM}} \text { (Starpharma } \\
\text { Pty Ltd., Australia) }\end{array}$ & {$[266,267]$} \\
\hline \multirow{2}{*}{$\begin{array}{c}\text { Chitosan and } \\
\text { Chitosan derivatives }\end{array}$} & Nasal spray & $\begin{array}{ll}- & \text { In vitro } \\
- & \text { In vivo } \\
\text { preclinical }\end{array}$ & \multirow{2}{*}{$\begin{array}{l}\text { Broad -spectrum } \\
\text { antiviral activity, } \\
\text { including against } \\
\text { MERS and } \\
\text { SARS-CoV-2 }\end{array}$} & \multirow{2}{*}{$\begin{array}{l}\text { Binding to and blocking } \\
\text { of the SARS-CoV-2 } \\
\text { S-protein and RBD and } \\
\text { subsequent inhibition of } \\
\text { the receptor-adhesin } \\
\text { connection and } \\
\text { viral entry }\end{array}$} & $\mathrm{n} / \mathrm{a}$ & \multirow[b]{2}{*}[146,147,268,269]{} \\
\hline & $\begin{array}{l}\text { Semifacial } \\
\text { respirator with } \\
\text { chitosan } \\
\text { nanoparticles }\end{array}$ & - $\quad$ Clinical trial & & & $\mathrm{n} / \mathrm{a}$ & \\
\hline \multirow{3}{*}{$\begin{array}{l}\text { Iota-, Lambda-, and } \\
\text { Kapa Carrageenan }\end{array}$} & Oral spray & $\begin{array}{ll}- & \text { In vitro } \\
- & \text { Clinical trial }\end{array}$ & \multirow{3}{*}{$\begin{array}{l}\text { Broad-spectrum } \\
\text { antiviral activity, } \\
\text { including against } \\
\text { SARS-CoV-2 }\end{array}$} & \multirow{3}{*}{$\begin{array}{c}\text { Formation of a } \\
\text { negatively charged } \\
\text { protective barrier on } \\
\text { mucus membranes, viral } \\
\text { binding and subsequent } \\
\text { viral aggregation, and } \\
\text { decreased viral } \\
\text { attachment and entry }\end{array}$} & $\begin{array}{c}\text { Coldamaris }^{\circledR} \\
\text { (Sigmapharm } \\
\text { Arzneimittel GmbH, } \\
\text { Austria) Throat Spray, } \\
\text { GripVis, Viruseptin, } \\
\text { Iovir }^{\circledR} \text { (Cube Pharma \& } \\
\text { Nutrition, Greece) }^{\text {Throat spray }} \\
\text { Theal }\end{array}$ & \multirow{3}{*}{$\begin{array}{l}{[15,132,149,150,} \\
270-278]\end{array}$} \\
\hline & Lozenges & $\begin{array}{ll}-\quad & \text { In vitro } \\
-\quad & \text { Clinical trial }\end{array}$ & & & $\begin{array}{c}\text { Coldamaris }{ }^{\circledR} \\
\text { (Sigmapharm } \\
\text { Arzneimittel GmbH, } \\
\text { Austria) lozenges, } \\
\text { Betadine }{ }^{\circledR} \text { (Avrio Health } \\
\text { L.P. Purdue Pharma Inc., } \\
\text { USA) lozenges, Lontax } \\
\text { Gola, Viruseptin }{ }^{\circledR} \\
\text { (Beampoint AB } \\
\text { Joint-stock company, } \\
\text { Sweden) lozenges }\end{array}$ & \\
\hline & Nasal spray & $\begin{array}{ll}- & \text { In vitro } \\
- & \text { Clinical trial }\end{array}$ & & & $\begin{array}{l}\text { Flo }^{\mathrm{TM}} \text { Travel nasal spray } \\
\text { (ENT Technologies Pty } \\
\text { Ltd., Australia), } \\
\text { Coldamaris pro. }{ }^{\circledR} \\
\text { (Sigmapharm } \\
\text { Arzneimittel GmbH, } \\
\text { Austria) nasal spray, } \\
\text { GripVis, Betadine }{ }^{\circledR} \\
\text { (Avrio Health L.P. } \\
\text { Pur-due Pharma Inc., } \\
\text { USA) Cold Defence } \\
\text { nasal spray, Viruseptin }{ }^{\circledR} \\
\text { (Beampoint AB } \\
\text { Joint-stock company, } \\
\text { Sweden), Agovirax } \\
\text { (GryNumber Health, } \\
\text { Ltd., Lithuania), Iovir } \\
\text { (Cube Pharma \& } \\
\text { Nutrition, Greece) nasal } \\
\text { spray, Nasitrol } \\
\text { nasal spray }\end{array}$ & \\
\hline
\end{tabular}


Table 1. Cont.

\begin{tabular}{|c|c|c|c|c|c|c|}
\hline Active Agent & $\begin{array}{c}\text { Form of } \\
\text { Application }\end{array}$ & $\begin{array}{l}\text { Type of Studies } \\
\text { Conducted/in } \\
\text { Progress }\end{array}$ & Efficacy & Mechanism of Action & $\begin{array}{l}\text { Available Marketed } \\
\text { Product(s) }\end{array}$ & References \\
\hline \multicolumn{7}{|c|}{ IV. NON-POLYMERIC NATURAL ANTIMICROBIAL AGENTS } \\
\hline Lactoferrin & $\begin{array}{l}\text { Intranasal } \\
\text { liposomal } \\
\text { suspension }\end{array}$ & Clinical trial & $\begin{array}{l}\text { Broad-spectrum } \\
\text { antimicrobial } \\
\text { activity, including } \\
\text { against SARS-CoV-2 }\end{array}$ & $\begin{array}{c}\text { Binding with } \\
\text { endogenous cell entry } \\
\text { factors, such as heparan } \\
\text { sulfate proteoglycans, } \\
\text { and SARS-CoV-2 } \\
\text { S-protein }\end{array}$ & $\mathrm{n} / \mathrm{a}$ & {$[279,280]$} \\
\hline Nitric oxide (NO) & Nasal spray & $\begin{array}{ll}-\quad & \text { In vitro } \\
-\quad & \text { Clinical trial }\end{array}$ & $\begin{array}{l}\text { Component of the } \\
\text { innate immunity }\end{array}$ & $\begin{array}{l}\text { Mediator of } \\
\text { immune-inflammatory } \\
\text { cascade defense } \\
\text { mechanisms }\end{array}$ & $\begin{array}{c}\text { Nitric oxide-releasing } \\
\left.\text { systems (NORS }{ }^{\mathrm{TM}}\right)- \\
\text { Enovid }^{\mathrm{TM}} / \mathrm{Vir}^{\mathrm{TM}} \\
\text { (SaNOtize Research and } \\
\text { Development Corp., } \\
\text { Canada) }\end{array}$ & {$[281,282]$} \\
\hline Type I Interferon & Nasal drops & Clinical trial & $\begin{array}{l}\text { Component of the } \\
\text { first-line nonspecific } \\
\text { (innate) immunity } \\
\text { against viruses }\end{array}$ & $\begin{array}{l}\text { Prevents a delay in INF-I } \\
\text { natural response }\end{array}$ & $\mathrm{n} / \mathrm{a}$ & [283-285] \\
\hline Xylitol & Nasal spray & $\begin{array}{ll}-\quad & \text { In vitro } \\
-\quad & \text { Clinical trials }\end{array}$ & $\begin{array}{l}\text { Antimicrobial } \\
\text { activity, including } \\
\text { against RSV and } \\
\text { SARS-CoV-2 }\end{array}$ & $\begin{array}{c}\text { Anti-adhesive effects, } \\
\text { prebiotic activity }\end{array}$ & $\begin{array}{l}\text { Xlear }^{\circledR} \text { (SaNOtize } \\
\text { Research and } \\
\text { Development Corp., } \\
\text { Canada) sinus care } \\
\text { products }\end{array}$ & {$[278,286-288]$} \\
\hline $\begin{array}{l}\text { Trypsin (from cod) } \\
+ \text { Glycerol }\end{array}$ & Oral spray & $\begin{array}{ll}-\quad & \text { In vitro } \\
-\quad & \text { Clinical trial } \\
& \text { (on athletes) }\end{array}$ & $\begin{array}{l}\text { Antiviral activity, } \\
\text { including against } \\
\text { HCoV-229E and } \\
\text { SARS-CoV-2 }\end{array}$ & $\begin{array}{c}\text { Formation of a physical } \\
\text { barrier on the mucosa } \\
\text { that entraps viral } \\
\text { particles (Glycerol); } \\
\text { proteolytic activity of } \\
\text { Trypsin on } \\
\text { trypsin-susceptible sites } \\
\text { along the SARS-CoV-2 } \\
\text { S-protein }\end{array}$ & $\begin{array}{c}\text { ColdZyme }^{\circledR} \text { (SaNOtize } \\
\text { Research and } \\
\text { Development Corp., } \\
\text { Canada) mouth spray, } \\
\text { Viruprotect mouth spray }\end{array}$ & [289-291] \\
\hline $\begin{array}{l}\text { Lysozyme (as } \\
\text { pretreatment agent } \\
\text { prior to nasal } \\
\text { vaccination) }\end{array}$ & Intranasal & $\begin{array}{l}\text { In vivo } \\
\text { preclinical }\end{array}$ & $\begin{array}{l}\text { Influenza, } \\
\text { SARS-CoV-2 }\end{array}$ & $\begin{array}{c}\text { Disruption of nasal } \\
\text { bacteria and subsequent } \\
\text { release of } \\
\text { pathogen-associated } \\
\text { molecular patterns, } \\
\text { which may act as } \\
\text { adjuvants to } \\
\text { enhance the } \\
\text { virus-specific antibody } \\
\text { response to vaccination }\end{array}$ & $\mathrm{n} / \mathrm{a}$ & [292] \\
\hline $\begin{array}{l}\text { Hydroxytyrosol }+ \\
\alpha \text {-cyclodextrin }\end{array}$ & Nasal spray & In vitro & $\begin{array}{l}\text { Broad-spectrum } \\
\text { antiviral activity }\end{array}$ & $\begin{array}{c}\text { Depletion of } \\
\text { sphingolipids from the } \\
\text { lipid rafts where the } \\
\text { ACE2 receptor, specific } \\
\text { for SARS-CoV-2, } \\
\text { localizes } \\
(\alpha \text {-cyclodextrin) }\end{array}$ & Endovir Stop & [293] \\
\hline \multirow[t]{2}{*}{$\begin{array}{l}\text { Longan extract (rich } \\
\text { in polyphenols) }\end{array}$} & Nasal spray & \multirow[t]{2}{*}{ - $\quad$ Clinical trial } & \multirow{2}{*}{$\begin{array}{l}\text { Potential antiviral, } \\
\text { including } \\
\text { anti-SARS-CoV-2 } \\
\text { activity }\end{array}$} & \multirow{2}{*}{$\begin{array}{l}\text { Potentially owed to the } \\
\text { polyphenols' unspecific } \\
\text { antiviral and } \\
\text { anti-inflammatory } \\
\text { properties }\end{array}$} & $\mathrm{n} / \mathrm{a}$ & \multirow[t]{2}{*}{ [294] } \\
\hline & Oral spray & & & & P80 Throat spray & \\
\hline $\begin{array}{c}\text { Flavonoid complex } \\
\text { (patent combination } \\
\text { Flavabac) }\end{array}$ & Oral spray & $\begin{array}{l}\text { In vivo } \\
\text { preclinical }\end{array}$ & $\begin{array}{l}\text { Broad-spectrum } \\
\text { antimicrobial } \\
\text { activity, including } \\
\text { against SARS-CoV-2 }\end{array}$ & $\begin{array}{l}\text { Antiviral activity of } \\
\text { flavonoids is owed to } \\
\text { their anti-oxidant } \\
\text { properties and ability to } \\
\text { interact with key } \\
\text { enzymes, receptors, and } \\
\text { membranes }\end{array}$ & $\begin{array}{l}\text { Cold \& Flu Guard } \\
\text { oral spray }\end{array}$ & [295-297] \\
\hline
\end{tabular}


Table 1. Cont.

\begin{tabular}{|c|c|c|c|c|c|c|}
\hline Active Agent & $\begin{array}{c}\text { Form of } \\
\text { Application }\end{array}$ & $\begin{array}{l}\text { Type of Studies } \\
\text { Conducted/in } \\
\text { Progress }\end{array}$ & Efficacy & Mechanism of Action & $\begin{array}{l}\text { Available Marketed } \\
\text { Product(s) }\end{array}$ & References \\
\hline \multicolumn{7}{|c|}{ V. IMMUNE-MODULATORS/ THERAPEUTICS WITH IMMUNE-MODULATORY ACTIVITY } \\
\hline $\begin{array}{c}\text { INNA-051 } \\
\text { (synthetic } \\
\text { PEGylated TLR2/6 } \\
\text { agonist) }\end{array}$ & Nasal spray & $\begin{array}{ll}- & \text { In vivo } \\
\text { - } & \text { preclinical } \\
& \text { Clinical trial }\end{array}$ & SARS-CoV-2 & $\begin{array}{l}\text { Reduction of the time } \\
\text { required for nasal } \\
\text { epithelial cells to } \\
\text { initiate the } \\
\text { innate immune } \\
\text { responses following } \\
\text { virus exposure }\end{array}$ & $\mathrm{n} / \mathrm{a}$ & [298-300] \\
\hline Ivermectin & $\begin{array}{l}\text { Oral (buccal) } \\
\text { drops }\end{array}$ & - $\quad$ Clinical trial & $\begin{array}{l}\text { Antiviral activity, } \\
\text { including against } \\
\text { SARS-CoV-2 }\end{array}$ & $\begin{array}{l}\text { Interaction with } \\
\text { SARS-CoV-2 S-protein } \\
\text { and host cells entry } \\
\text { factors, and subsequent } \\
\text { inhibition of viral cell } \\
\text { entry; blocking of the } \\
\text { nuclear transport of the } \\
\text { SARS-CoV-2 viral } \\
\text { proteins by action on } \\
\text { Importin superfamily; } \\
\text { blocking of viral } \\
\text { replication and } \\
\text { assembly; } \\
\text { immune-modulatory } \\
\text { properties }\end{array}$ & $\mathrm{n} / \mathrm{a}$ & {$[272,275,301]$} \\
\hline \multicolumn{7}{|c|}{ VI. OTHER } \\
\hline $\begin{array}{l}\text { Probiotic strain } \\
\text { Lacticaseibacillus } \\
\text { casei AMBR2 }\end{array}$ & Nasal spray & In vitro & $\begin{array}{l}\text { Staphylococcus } \\
\text { aureus, Moraxella } \\
\text { catarrhalis, and } \\
\text { Haemophilus } \\
\text { influenzae }\end{array}$ & $\begin{array}{c}\text { Secretion of } \\
\text { antimicrobial substances } \\
\text { such as lactic acid, } \\
\text { bacteriocins, and } \mathrm{H}_{2} \mathrm{O}_{2}\end{array}$ & $\begin{array}{c}\mathrm{n} / \mathrm{a} \\
\text { LiviaOne Probiotics } \\
\text { Nasal Spray }{ }^{\mathrm{b}}\end{array}$ & {$[183,184,302]$} \\
\hline $\begin{array}{l}\text { Ethyl lauroyl arginate } \\
\text { hydrochloride } \\
\text { (ELAH) }\end{array}$ & Nasal spray & $\begin{array}{ll}-\quad & \text { In vivo } \\
\text { preclinical } \\
\text { - }\end{array}$ & $\begin{array}{l}\text { Broad-spectrum } \\
\text { antimicrobial } \\
\text { activity, including } \\
\text { against SARS-CoV-2 }\end{array}$ & $\begin{array}{l}\text { Formation of positively } \\
\text { charged physical barrier } \\
\text { on mucosa and } \\
\text { inhibition of } \\
\text { viral adhesion }\end{array}$ & Covixyl-V & [300] \\
\hline Silver nanoparticles & $\begin{array}{l}\text { Nasal and } \\
\text { oral rinse }\end{array}$ & $\begin{array}{ll}- & \text { In vitro } \\
- & \text { Clinical trial }\end{array}$ & $\begin{array}{l}\text { Broad-spectrum } \\
\text { antimicrobial } \\
\text { activity, including } \\
\text { against SARS-CoV-2 }\end{array}$ & $\begin{array}{l}\text { Interference with the } \\
\text { structural proteins of the } \\
\text { virus and inhibiting their } \\
\text { ability to bind with cell } \\
\text { receptors, or bind to } \\
\text { genetic material of } \\
\text { viruses and inhibiting } \\
\text { their replication }\end{array}$ & $\begin{array}{c}\text { ViruStat-RDS nasal } \\
\text { spray (+Xylitol), Silvacol } \\
\text { nasal spray }\end{array}$ & {$[303,304]$} \\
\hline
\end{tabular}

${ }^{a}$ product not available, ${ }^{b}$ contains other Lactobacilus strains.

Beyond the active agents listed in Table 1, many more candidates are hypothesized but not yet studied, in either in vitro or in vivo experiments, for their actual efficacy in the nasal and oral prophylaxis of SARS-CoV-2. Such are phenolic compounds with proven efficacy against other respiratory viruses (e.g., Quercetin, Hesperidin, Diosmin, Resveratrol) [167,305-308], essential oils [309-312], quaternary ammonium compounds with broadspectrum antimicrobial activity [313] (e.g., Cetylpyridinium chloride, available in the nasal spray product "Halo ${ }^{\mathrm{TM}}$ "(Oasis Consumer Healthcare, USA) [17]), statins [314], and others strictly related to the SARS-CoV-2 entry mechanism therapeutics (e.g., ACE2 agonists [315] and ACE2-coated nanoparticles [316]). On the other hand, some very potent antisepticsviz., Hydrogen peroxide and Chlorhexidine, have not demonstrated the expected efficacy against SARS-CoV-2 [317-319]. Thus, to avoid speculation, thorough investigations are required to prove the applicability of each potential candidate in the local prophylaxis of the currently most significant threat for respiratory infection-the SARS-CoV-2 virus.

\section{Conclusions}

The nasal and oral cavities play an essential and determinative role for the development of a respiratory infection since they establish the first contact with the airborne and respiratory droplet-transmitted pathogens. It is, therefore, a primary goal to focus on the mucosal immunity and defense capacity, especially in the time of COVID-19 pandemic. 
As our research shows, more than 30 well-known or expressly modified molecules in the past two years are being investigated for their potency to improve the local resistance of the nasal and oral pathways against SARS-CoV-2. Although many are showing promising results, the delivery form/vehicle and the delivery device are addressed and are a subject of optimization in very few of these studies. It is our opinion that a thorough biopharmaceutical approach may contribute to extending the anti-SARS-CoV-2 capacity of even more therapeutics. Furthermore, regarding the nasal and oromucosal protective formulations, two other niches exist that have not been so extensively explored in terms of COVID-19 infection-the ability of such forms to restore the sense of smell and taste and reduce viral spread.

Author Contributions: Conceptualization, N.I.; methodology, N.I., V.A. and K.N.; investigation, N.I., Y.S. and G.G.; writing-original draft preparation N.I.; writing—review and editing, V.A. and K.N.; visualization, N.I., Y.S. and G.G.; supervision, V.A. and K.N.; project administration, N.I.; funding acquisition, V.A. All authors have read and agreed to the published version of the manuscript.

Funding: This research was funded by Medical University-Varna.

Institutional Review Board Statement: Not applicable.

Informed Consent Statement: Not applicable.

Data Availability Statement: Data sharing not applicable.

Acknowledgments: The authors would like to express their acknowledgement to the supportersMedical University of Varna, Varna, Bulgaria.

Conflicts of Interest: The authors declare no conflict of interest.

\section{References}

1. Stilianakis, N.I.; Drossinos, Y. Dynamics of infectious disease transmission by inhalable respiratory droplets. J. R. Soc. Interface 2010, 7, 1355-1366. [CrossRef]

2. Dasaraju, P.V.; Liu, C. Infections of the respiratory system. In Medical Microbiology, 4th ed.; Baron, S., Ed.; University of Texas Medical Branch at Galveston: Galveston, TX, USA, 1996; ISBN 0-9631172-1-1.

3. Cegolon, L.; Javanbakht, M.; Mastrangelo, G. Nasal disinfection for the prevention and control of COVID-19: A scoping review on potential chemo-preventive agents. Int. J. Hyg. Environ. Health 2020, 230, 113605. [CrossRef] [PubMed]

4. Joffe, S. Evaluating SARS-CoV-2 Vaccines After Emergency Use Authorization or Licensing of Initial Candidate Vaccines. JAMA 2021, 325, 221-222. [CrossRef] [PubMed]

5. Knezevic, I.; Liu, M.A.; Peden, K.; Zhou, T.; Kang, H.-N. Development of mRNA Vaccines: Scientific and Regulatory Issues. Vaccines 2021, 9, 81. [CrossRef] [PubMed]

6. Amanpour, S. The Rapid Development and Early Success of COVID 19 Vaccines Have Raised Hopes for Accelerating the Cancer Treatment Mechanism. Arch. Razi Inst. 2021, 76, 1-6.

7. Baron, S.; Fons, M.; Albrecht, T. Viral pathogenesis. In Medical Microbiology, 4th ed.; Baron, S., Ed.; University of Texas Medical Branch at Galveston: Galveston, TX, USA, 1996; ISBN 0-9631172-1-1.

8. Linden, S.K.; Sutton, P.; Karlsson, N.G.; Korolik, V.; McGuckin, M.A. Mucins in the mucosal barrier to infection. Mucosal Immunol. 2008, 1, 183-197. [CrossRef]

9. Wiegand, T.; Fratini, M.; Frey, F.; Yserentant, K.; Liu, Y.; Weber, E.; Galior, K.; Ohmes, J.; Braun, F.; Herten, D.-P.; et al. Forces during cellular uptake of viruses and nanoparticles at the ventral side. Nat. Commun. 2020, 11, 32. [CrossRef]

10. Lai, S.K.; Wang, Y.-Y.; Wirtz, D.; Hanes, J. Micro- and macrorheology of mucus. Adv. Drug Deliv. Rev. 2009, 61, 86-100. [CrossRef]

11. Cole, P. Physiology of the nose and paranasal sinuses. In Diseases of the Sinuses; Gershwin, M.E., Incaudo, G.A., Eds.; Humana Press: Totowa, NJ, USA, 1996; pp. 33-51, ISBN 978-1-4612-0225-7.

12. Tratnjek, L.; Kreft, M.; Kristan, K.; Kreft, M.E. Ciliary beat frequency of in vitro human nasal epithelium measured with the simple high-speed microscopy is applicable for safety studies of nasal drug formulations. Toxicol. Vitr. 2020, 66, 104865. [CrossRef]

13. Shaikh, R.; Raj Singh, T.R.; Garland, M.J.; Woolfson, A.D.; Donnelly, R.F. Mucoadhesive drug delivery systems. J. Pharm. Bioallied Sci. 2011, 3, 89-100.

14. Mallakpour, S.; Azadi, E.; Hussain, C.M. Protection, disinfection, and immunization for healthcare during the COVID-19 pandemic: Role of natural and synthetic macromolecules. Sci. Total Environ. 2021, 776, 145989. [CrossRef]

15. Moakes, R.J.A.; Davies, S.P.; Stamataki, Z.; Grover, L.M. Formulation of a composite nasal spray enabling enhanced surface coverage and prophylaxis of SARS-COV-2. Adv. Mater. 2021, 33, 2008304. [CrossRef] 
16. Sandri, G.; Saporito, F.; Ferrari, F.; Bonferoni, M.C.; Rossi, S.; Caramella, C. In vitro evaluation of a protective nasal spray: Measurements of mucoadhesion and reconstructive barrier properties towards a tracheobronchial reconstruct. J. Drug Deliv. Sci. Technol. 2015, 30, 368-374. [CrossRef]

17. Mukherjee, P.K.; Esper, F.; Buchheit, K.; Arters, K.; Adkins, I.; Ghannoum, M.A.; Salata, R.A. Randomized, double-blind, placebo-controlled clinical trial to assess the safety and effectiveness of a novel dual-action oral topical formulation against upper respiratory infections. BMC Infect. Dis. 2017, 17, 74. [CrossRef]

18. Papadopoulos, N.G.; Megremis, S.; Kitsioulis, N.A.; Vangelatou, O.; West, P.; Xepapadaki, P. Promising approaches for the treatment and prevention of viral respiratory illnesses. J. Allergy Clin. Immunol. 2017, 140, 921-932. [CrossRef]

19. Mellis, C. Acute upper respiratory tract infections in childhood. In Practical Paediatrics, 6th ed.; Roberton, D.M., South, M., Eds.; Churchill Livingstone/Elsevier: London, UK, 2006; pp. 475-481, ISBN 9780443102806.

20. Myint, S. Microbiology and epidemiology of upper respiratory tract infections. In Respiratory Infections in Allergy and Asthma, 1st ed.; Johnston, S.L., Papadopoulos, N.G., Eds.; CRC Press: Boca Raton, FL, USA, 2003; ISBN 978-0824741266.

21. Cappelletty, D. Microbiology of bacterial respiratory infections. Pediatr. Infect. Dis. J. 1998, 17, S55-S61. [CrossRef]

22. Wu, D.; Wu, T.; Liu, Q.; Yang, Z. The SARS-CoV-2 outbreak: What we know. Int. J. Infect. Dis. 2020, 94, 44-48. [CrossRef]

23. Brachman, P.S. Epidemiology. In Medical Microbiology, 4th ed.; Baron, S., Ed.; University of Texas Medical Branch at Galveston: Galveston, TX, USA, 1996; ISBN 0-9631172-1-1.

24. Fenner, F. Epidemiology and evolution. In Medical Microbiology, 4th ed.; Baron, S., Ed.; University of Texas Medical Branch at Galveston: Galveston, TX, USA, 1996; ISBN 0-9631172-1-1.

25. Peterson, J.W. Bacterial pathogenesis. In Medical Microbiology, 4th ed.; Baron, S., Ed.; University of Texas Medical Branch at Galveston: Galveston, TX, USA, 1996; ISBN 0-9631172-1-1.

26. Kuek, L.E.; Lee, R.J. First contact: The role of respiratory cilia in host-pathogen interactions in the airways. Am. J. Physiol. Lung Cell. Mol. Physiol. 2020, 319, L603-L619. [CrossRef]

27. Johnson, J.A. Pathogenesis of bacterial infections of the respiratory tract. Br. J. Biomed. Sci. 1995, 52, 157-161.

28. Wanner, A. Clinical aspects of mucociliary transport. Am. Rev. Respir. Dis. 1977, 116, 73-125.

29. Cole, P.; Wilson, R. Host-microbial interrelationships in respiratory infection. Chest 1989, 95, 217S-221S. [CrossRef]

30. Wilson, R.; Pitt, T.; Taylor, G.; Watson, D.; MacDermot, J.; Sykes, D.; Roberts, D.; Cole, P. Pyocyanin and 1-hydroxyphenazine produced by Pseudomonas aeruginosa inhibit the beating of human respiratory cilia in vitro. J. Clin. Investig. 1987, 79, 221-229. [CrossRef] [PubMed]

31. Denny, F.W. Effect of a toxin produced by Haemophilus influenzae on ciliated respiratory epithelium. J. Infect. Dis. 1974, 129, 93-100. [CrossRef] [PubMed]

32. Chilvers, M.A.; McKean, M.; Rutman, A.; Myint, B.S.; Silverman, M.; O'Callaghan, C. The effects of coronavirus on human nasal ciliated respiratory epithelium. Eur. Respir. J. 2001, 18, 965-970. [CrossRef]

33. Fu, Y.; Tong, J.; Meng, F.; Hoeltig, D.; Liu, G.; Yin, X.; Herrler, G. Ciliostasis of airway epithelial cells facilitates influenza A virus infection. Vet. Res. 2018, 49, 65. [CrossRef]

34. Griggs, T.F.; Bochkov, Y.A.; Basnet, S.; Pasic, T.R.; Brockman-Schneider, R.A.; Palmenberg, A.C.; Gern, J.E. Rhinovirus C targets ciliated airway epithelial cells. Respir. Res. 2017, 18, 84. [CrossRef]

35. Look, D.C.; Walter, M.J.; Williamson, M.R.; Pang, L.; You, Y.; Sreshta, J.N.; Johnson, J.E.; Zander, D.S.; Brody, S.L. Effects of paramyxoviral infection on airway epithelial cell Foxj1 expression, ciliogenesis, and mucociliary function. Am. J. Pathol. 2001 159, 2055-2069. [CrossRef]

36. Mata, M.; Sarrion, I.; Armengot, M.; Carda, C.; Martinez, I.; Melero, J.A.; Cortijo, J. Respiratory syncytial virus inhibits ciliagenesis in differentiated normal human bronchial epithelial cells: Effectiveness of N-acetylcysteine. PLoS ONE 2012, 7, e48037. [CrossRef]

37. Smith, C.M.; Kulkarni, H.; Radhakrishnan, P.; Rutman, A.; Bankart, M.J.; Williams, G.; Hirst, R.A.; Easton, A.J.; Andrew, P.W.; O'Callaghan, C. Ciliary dyskinesia is an early feature of respiratory syncytial virus infection. Eur. Respir. J. 2014, 43, 485-496. [CrossRef]

38. Abraham, S.N.; Sharon, N.; Ofek, I.; Schwartzman, J.D. Adhesion and colonization. In Molecular Medical Microbiology, 2nd ed.; Tang, Y.-W., Sussman, M., Liu, D., Poxton, I., Schwartzman, J., Eds.; Academic Press: Cambridge, MA, USA, 2015; pp. 409-421, ISBN 9780123971692.

39. Sanyal, S. How SARS-CoV-2 (COVID-19) spreads within infected hosts-What we know so far. Emerg. Top. Life Sci. 2020, 4, 371-378.

40. Hallstrom, K.N.; McCormick, B.A. Pathogenicity islands: Origins, structure, and roles in bacterial pathogenesis. In Molecular Medical Microbiology, 2nd ed.; Tang, Y.-W., Sussman, M., Liu, D., Poxton, I., Schwartzman, J., Eds.; Academic Press: Cambridge, MA, USA, 2015; pp. 303-314, ISBN 9780123971692.

41. Nash, A.A.; Dalziel, R.G.; Fitzgerald, J.R. Attachment to and entry of microorganisms into the body. In Mims' Pathogenesis of Infectious Disease, 6th ed.; Nash, A.A., Dalziel, R.G., Fitzgerald, J.R., Eds.; Academic Press: Cambridge, MA, USA, 2015; pp. 9-49, ISBN 9780123971883

42. Li, W.; Moore, M.J.; Vasilieva, N.; Sui, J.; Wong, S.K.; Berne, M.A.; Somasundaran, M.; Sullivan, J.L.; Luzuriaga, K.; Greenough, T.C.; et al. Angiotensin-converting enzyme 2 is a functional receptor for the SARS corona-virus. Nature 2003, 426, 450-454. [CrossRef] [PubMed] 
43. Raj, V.S.; Mou, H.; Smits, S.L.; Dekkers, D.H.W.; Müller, M.A.; Dijkman, R.; Muth, D.; Demmers, J.A.A.; Zaki, A.; Fouchier, R.A.M.; et al. Dipeptidyl peptidase 4 is a functional receptor for the emerging human coronavirus-EMC. Nature 2013, 495, 251-254. [CrossRef] [PubMed]

44. Collins, A.R. HLA class I antigen serves as a receptor for human coronavirus OC43. Immunol. Investig. 1993, 22, 95-103. [CrossRef] [PubMed]

45. Dijkman, R.; Jebbink, M.F.; Koekkoek, S.M.; Deijs, M.; Jónsdóttir, H.R.; Molenkamp, R.; Ieven, M.; Goossens, H.; Thiel, V.; van der Hoek, L. Isolation and characterization of current human coronavirus strains in primary human epithelial cell cultures reveal differences in target cell tropism. J. Virol. 2013, 87, 6081-6090. [CrossRef] [PubMed]

46. Essaidi-Laziosi, M.; Brito, F.; Benaoudia, S.; Royston, L.; Cagno, V.; Fernandes-Rocha, M.; Piuz, I.; Zdobnov, E.; Huang, S.; Constant, S.; et al. Propagation of respiratory viruses in human airway epithelia reveals persistent virus-specific signatures. J. Allergy Clin. Immunol. 2018, 141, 2074-2084. [CrossRef] [PubMed]

47. Thompson, C.I.; Barclay, W.S.; Zambon, M.C.; Pickles, R.J. Infection of Human Airway Epithelium by Human and Avian Strains of Influenza A Virus. J. Virol. 2006, 80, 8060-8068. [CrossRef] [PubMed]

48. Pittet, L.A.; Hall-Stoodley, L.; Rutkowski, M.R.; Harmsen, A.G. Influenza virus infection decreases tracheal mucociliary velocity and clearance of Streptococcus pneumoniae. Am. J. Respir. Cell Mol. Biol. 2010, 42, 450-460. [CrossRef]

49. Bella, J.; Kolatkar, P.R.; Marlor, C.W.; Greve, J.M.; Rossmann, M.G. The Structure of the Two Amino-Terminal Domains of Human ICAM-1 Suggests How it Functions as a Rhinovirus Receptor and as an LFA-1 Integrin Ligand. Proc. Natl. Acad. Sci. USA 1998, 95, 4140-4145. [CrossRef]

50. Sakakura, Y.; Sasaki, Y.; Togo, Y.; Wagner, H.N., Jr.; Hornick, R.B.; Schwartz, A.R.; Proctor, D.F. Mucociliary function during experimentally induced rhinovirus infection in man. Ann. Otol. Rhinol. Laryngol. 1973, 82, 203-211. [CrossRef]

51. Letko, M.; Marzi, A.; Munster, V. Functional assessment of cell entry and receptor usage for SARS-CoV-2 and other line-age B betacoronaviruses. Nat. Microbiol. 2020, 5, 562-569. [CrossRef]

52. Lee, I.; Nakayama, T.; Jiang, S.; Goltsev, Y.; Schürch, C.; Zhu, B.; McIlwain, D.; Chu, P.; Chen, H.; Tzankov, A.; et al. SARS-CoV-2 entry factors are expressed in nasal, ocular, and oral tissues: Implications for COVID-19 prophylaxes/therapeutics. J. Allergy Clin. Immunol. 2021, 147, AB2. [CrossRef]

53. Mete, A.; Akbudak, İ.H. Functional anatomy and physiology of airway. In Tracheal Intubation; Erbay, R.H., Ed.; IntechOpen: London, UK, 2018; ISBN 978-1-78923-489-3.

54. Triana, B.E.G.; Ali, A.H.; León, I.B.G. Mouth breathing and its relationship to some oral and medical conditions: Physiopathological mechanisms involved. Rev. Habanera Cienc. Med. 2016, 15, 200-212.

55. Gizurarson, S. Anatomical and histological factors affecting intranasal drug and vaccine delivery. Curr. Drug Deliv. 2012, 9, 566-582. [CrossRef] [PubMed]

56. Harkema, J.R.; Carey, S.A.; Wagner, J.G. The nose revisited: A brief review of the comparative structure, function, and toxicologic pathology of the nasal epithelium. Toxicol. Pathol. 2006, 34, 252-269. [CrossRef]

57. Ozturk, A.B.; Damadoglu, E.; Karakaya, G.; Kalyoncu, A.F. Does nasal hair (vibrissae) density affect the risk of developing asthma in patients with seasonal rhinitis? Int. Arch. Allergy Immunol. 2011, 156, 75-80. [CrossRef]

58. Beule, A.G. Physiology and pathophysiology of respiratory mucosa of the nose and the paranasal sinuses. GMS Curr. Top. Otorhinolaryngol. Head Neck Surg. 2010, 9, 1-24.

59. Anand, S.; Mayya, Y.S. Size distribution of virus laden droplets from expiratory ejecta of infected subjects. Sci. Rep. 2020, 10, 21174. [CrossRef]

60. Wang, Y.; Xu, G.; Huang, Y.-W. Modeling the load of SARS-CoV-2 virus in human expelled particles during coughing and speaking. PLOS ONE 2020, 15, e0241539.

61. Bustamante-Marin, X.M.; Ostrowski, L.E. Cilia and Mucociliary Clearance. Cold Spring Harb. Perspect. Biol. 2017,9 , a028241. [CrossRef]

62. Mitchison, T.J.; Mitchison, H.M. How cilia beat. Nature 2010, 463, 308-309. [CrossRef]

63. Debertin, A.S.; Tschernig, T.; Tönjes, H.; Kleemann, W.J.; Tröger, H.D.; Pabst, R. Nasal-associated lymphoid tissue (NALT): Frequency and localization in young children. Clin. Exp. Immunol. 2003, 134, 503-507. [CrossRef] [PubMed]

64. Fujimura, Y. Evidence of M cells as portals of entry for antigens in the nasopharyngeal lymphoid tissue of humans. Virchows Arch. 2000, 436, 560-566. [CrossRef] [PubMed]

65. Lobaina Mato, Y. Nasal route for vaccine and drug delivery: Features and current opportunities. Int. J. Pharm. 2019, 572, 118813. [CrossRef]

66. Moini, J.; Piran, P. Cranial nerves. In Functional and Clinical Neuroanatomy, 1st ed.; Moini, J., Piran, P., Eds.; Academic Press: Cambridge, MA, USA, 2020; pp. 319-344. ISBN 9780128174258.

67. Alberty, J.; Stoll, W.; Rudack, C. The effect of endogenous nitric oxide on mechanical ciliostimulation of human nasal mucosa. Clin. Exp. Allergy 2006, 36, 1254-1259. [CrossRef]

68. Swart, S.J.; van der Baan, S.; Steenbergen, J.J.E.; Nauta, J.J.P.; van Kamp, G.J.; Biewenga, J. Immunoglobulin concentrations in nasal secretions differ between patients with an IgE-mediated rhinopathy and a non-IgE-mediated rhinopathy. J. Allergy Clin. Immunol. 1991, 88, 612-619. [CrossRef]

69. Meredith, S.D.; Raphael, G.D.; Baraniuk, J.N.; Banks, S.M.; Kaliner, M.A. The pathophysiology of rhinitis. III. The control of IgG secretion. J. Allergy Clin. Immunol. 1989, 84, 920-930. [CrossRef] 
70. Huang, N.; Pérez, P.; Kato, T.; Mikami, Y.; Okuda, K.; Gilmore, R.C.; Conde, C.D.; Gasmi, B.; Stein, S.; Beach, M.; et al. SARS-CoV-2 infection of the oral cavity and saliva. Nat. Med. 2021, 27, 892-903. [CrossRef] [PubMed]

71. Altaie, A.M.; Hamdy, R.; Venkatachalam, T.; Hamoudi, R.; Soliman, S.S.M. Estimating the viral loads of SARS-CoV-2 in the oral cavity when complicated with periapical lesions. BMC Oral Health 2021, 21, 567. [CrossRef]

72. Xiang, Z.; Koo, H.; Chen, Q.; Zhou, X.; Liu, Y.; Simon-Soro, A. Potential implications of SARS-CoV-2 oral infection in the host microbiota. J. Oral Microbiol. 2020, 13, 1853451. [CrossRef]

73. Walker, D.H. Interactions of pathogens with the host. In Pathobiology of Human Disease; MacManus, L.M., Mitchel, R.N., Eds.; Academic Press: Cambridge, MA, USA, 2014; pp. 214-216, ISBN 978-0-12-386457-4.

74. Gaeckle, N.T.; Pragman, A.A.; Pendleton, K.M.; Baldomero, A.K.; Criner, G.J. The Oral-Lung Axis: The Impact of Oral Health on Lung Health. Respir. Care 2020, 65, 1211-1220. [CrossRef]

75. De Steenhuijsen Piters, W.A.A.; Sanders, E.A.M.; Bogaert, D. The role of the local microbial ecosystem in respiratory health and disease. Philos. Trans. R. Soc. Lond. B Biol. Sci. 2015, 370, 20140294. [CrossRef] [PubMed]

76. Lester, R.A.; Hoit, J.D. Nasal and oral inspiration during natural speech breathing. J. Speech Lang. Hear. Res. 2014, 57, 734-742. [CrossRef]

77. Abreu, R.R.; Rocha, R.L.; Lamounier, J.A.; Guerra, A.F.M. Etiology, clinical manifestations and concurrent findings in mouthbreathing children. J. Pediatr. 2008, 84, 529-535. [CrossRef]

78. Bradley, D. Physiotherapy in rehabilitation of breathing pattern disorders. In Recognizing and Treating Breathing Disorders, 2nd ed.; Chaitow, L., Bradley, D., Gilbert, C., Eds.; Churchill Livingstone/Elsevier: London, UK, 2014; pp. 185-196, ISBN 978-0-7020-4980-4.

79. Lundberg, J.O.; Weitzberg, E. Nasal nitric oxide in man. Thorax 1999, 54, 947-952. [CrossRef] [PubMed]

80. Balasubramanian, S.; Vinayachandran, D. Bioaerosols from mouth-breathing: Under-recognized transmissible mode in COVID-19? Can. Commun. Dis. Rep. 2021, 47, 276-278. [CrossRef]

81. Martel, J.; Ko, Y.-F.; Young, J.D.; Ojcius, D.M. Could nasal nitric oxide help to mitigate the severity of COVID-19? Microbes Infect. 2020, 22, 168-171. [CrossRef]

82. Lotz, C.; Muellenbach, R.M.; Meybohm, P.; Mutlak, H.; Lepper, P.M.; Rolfes, C.-B.; Peivandi, A.; Stumpner, J.; Kredel, M.; Kranke, P.; et al. Effects of inhaled nitric oxide in COVID-19-induced ARDS-Is it worthwhile? Acta Anaesthesiol. Scand. 2021, 65, 629-632. [CrossRef]

83. Wu, R.-Q.; Zhang, D.-F.; Tu, E.; Chen, Q.-M.; Chen, W. The mucosal immune system in the oral cavity-an orchestra of T cell diversity. Int. J. Oral Sci. 2014, 6, 125-132. [CrossRef]

84. Deo, P.N.; Deshmukh, R. Oral microbiome: Unveiling the fundamentals. J. Oral Maxillofac. Pathol. 2019, $23,122-128$.

85. La Rosa, G.R.M.; Libra, M.; de Pasquale, R.; Ferlito, S.; Pedullà, E. Association of Viral Infections with Oral Cavity Lesions: Role of SARS-CoV-2 Infection. Front. Med. 2021, 7, 571214. [CrossRef]

86. Xu, H.; Zhong, L.; Deng, J.; Peng, J.; Dan, H.; Zeng, X.; Li, T.; Chen, Q. High expression of ACE2 receptor of 2019-nCoV on the epithelial cells of oral mucosa. Int. J. Oral Sci. 2020, 12, 8. [CrossRef] [PubMed]

87. Araújo, M.M. The Importance of Reducing the Viral Load in the Oral Cavity. Int. J. Oral Dent. Health 2021, 7, 124.

88. Baghizadeh Fini, M. Oral saliva and COVID-19. Oral Oncol. 2020, 108, 104821. [CrossRef]

89. Zhang, H.; Kang, Z.; Gong, H.; Xu, D.; Wang, J.; Li, Z.; Li, Z.; Cui, X.; Xiao, J.; Zhan, J.; et al. Digestive system is a potential route of COVID-19: An analysis of single-cell coexpression pattern of key proteins in viral entry process. Gut 2020, 69, 1010-1018. [CrossRef]

90. Zhou, D.; Wang, Q.; Liu, H. Coronavirus disease 2019 and the gut-lung axis. Int. J. Infect. Dis. 2021, 113, 300-307. [CrossRef] [PubMed]

91. De Oliveira, G.L.V.; Oliveira, C.N.S.; Pinzan, C.F.; de Salis, L.V.V.; de Barros Cardoso, C.R. Microbiota Modulation of the Gut-Lung Axis in COVID-19. Front. Immunol. 2021, 12, 635471. [CrossRef]

92. Guo, M.; Tao, W.; Flavell, R.A.; Zhu, S. Potential intestinal infection and faecal-oral transmission of SARS-CoV-2. Nat. Rev. Gastroenterol. Hepatol. 2021, 18, 269-283. [CrossRef]

93. Dibner, J.J. Direct COVID-19 infection of enterocytes: The role of hypochlorhydria. Am. J. Infect. Control 2021, 49, 385-386. [CrossRef]

94. Price, E. Could the severity of COVID-19 be increased by low gastric acidity? Crit. Care 2020, 24, 456. [CrossRef]

95. Zhou, J.; Li, C.; Zhao, G.; Chu, H.; Wang, D.; Yan, H.H.-N.; Poon, V.K.-M.; Wen, L.; Wong, B.H.-Y.; Zhao, X.; et al. Human intestinal tract serves as an alternative infection route for Middle East respiratory syndrome coronavirus. Sci. Adv. 2017, 3, eaao4966. [CrossRef]

96. Bao, L.; Zhang, C.; Dong, J.; Zhao, L.; Li, Y.; Sun, J. Oral Microbiome and SARS-CoV-2: Beware of Lung Co-infection. Front. Microbiol. 2020, 11, 1840. [CrossRef] [PubMed]

97. World Health Organization. Transmission of SARS-CoV-2: Implications for Infection Prevention Precautions. Scientific Brief. Available online: https:/ / www.who.int/news-room/commentaries/detail/transmission-of-sars-cov-2-implications-for-infectionprevention-precautions (accessed on 15 August 2020).

98. WHO. Controlling the Spread of Infectious Diseases. Advancing the Right to Health: The Vital Role of Law; World Health Organization: Geneva, Switzerland, 2017; pp. 151-164, ISBN 9789241511384. 
99. Keeling, M.J.; Rohani, P. Controlling infectious diseases. In Modeling Infectious Diseases in Humans and Animals; Keeling, M.J., Rohani, P., Eds.; Princeton University Press: Princeton, NJ, USA, 2008; pp. 291-336, ISBN 9781400841035.

100. Jain, M.; Kim, S.T.; Xu, C.; Li, H.; Rose, G. Efficacy and Use of Cloth Masks: A Scoping Review. Cureus 2020, 12, e10423. [CrossRef] [PubMed]

101. Yang, P.; Seale, H.; MacIntyre, C.R.; Zhang, H.; Zhang, Z.; Zhang, Y.; Wang, X.; Li, X.; Pang, X.; Wang, Q. Mask-wearing and respiratory infection in healthcare workers in Beijing, China. Braz. J. Infect. Dis. 2011, 15, 102-108. [CrossRef]

102. Howard, J.; Huang, A.; Li, Z.; Tufekci, Z.; Zdimal, V.; van der Westhuizen, H.-M.; von Delft, A.; Price, A.; Fridman, L.; Tang, L.-H.; et al. An evidence review of face masks against COVID-19. Proc. Natl. Acad. Sci. USA 2021, 118, e2014564118. [CrossRef]

103. Davies, A.; Thompson, K.-A.; Giri, K.; Kafatos, G.; Walker, J.; Bennet, A. Testing the efficacy of homemade masks: Would they protect in an influenza pandemic? Disaster Med. Public Health Prep. 2013, 7, 413-418. [CrossRef] [PubMed]

104. Hemmer, C.J.; Hufert, F.; Siewert, S.; Reisinger, E. Protection from COVID-19: The efficacy of face masks. Dtsch. Arztebl. Int. 2021, 118, 59-65. [CrossRef]

105. Neupane, B.B.; Mainali, S.; Sharma, A.; Giri, B. Optical microscopic study of surface morphology and filtering efficiency of face masks. PeerJ 2019, 26, e7142. [CrossRef]

106. Furuhashi, M. A study on the microbial filtration efficiency of surgical face masks-With special reference to the non-woven fabric mask. Bull. Tokyo Med. Dent. Univ. 1978, 25, 7-15.

107. Tagle, M.G.; Cilia-López, V.G. The Massive Misuse of Face Mask as a Risk to COVID-19 Pandemic in Latin American: The Case of Mexico. PREPRINT (Version 1). 2021. Available online: https://www.researchsquare.com/article/rs-323037/v1 (accessed on 13 October 2021).

108. Neilson, S. The surgical mask is a bad fit for risk reduction. Can. Med. Assoc. J. 2016, 188, 606-607. [CrossRef]

109. Cheng, Y.; Ma, N.; Witt, C.; Rapp, S.; Wild, P.S.; Andreae, M.O.; Pöschl, U.; Su, H. Face masks effectively limit the probability of SARS-CoV-2 transmission. Science 2021, 372, 1439-1443. [CrossRef]

110. Chou, R.; Dana, T.; Jungbauer, R.; Weeks, C.; McDonagh, M.S. Masks for Prevention of Respiratory Virus Infections, Including SARS-CoV-2, in Health Care and Community Settings. Ann. Intern. Med. 2020, 173, 542-555. [CrossRef] [PubMed]

111. Chou, R.; Dana, T.; Jungbauer, R.; Weeks, C. Update Alert 3: Masks for Prevention of Respiratory Virus Infections, Including SARS-CoV-2, in Health Care and Community Settings. Ann. Intern. Med. 2020, 173, 169. [CrossRef] [PubMed]

112. Chou, R.; Dana, T.; Jungbauer, R.; Weeks, C. Update Alert 4: Masks for Prevention of Respiratory Virus Infections, Including SARS-CoV-2, in Health Care and Community Settings. Ann. Intern. Med. 2021, 174, W24. [CrossRef] [PubMed]

113. Da Silva, A.M.; Willmore, L.J. Posttraumatic epilepsy. In Handbook of Clinical Neurology; Stefan, H., Theodore, W.H., Eds.; Elsevier: Amsterdam, The Netherlands, 2012; Volume 108, pp. 585-599, ISBN 978-0-444-52899-5.

114. Pollard, A.J.; Bijker, E.M. A guide to vaccinology: From basic principles to new developments. Nat. Rev. Immunol. 2021, 21, 83-100. [CrossRef]

115. Abbas, A.T.; El-Kafrawy, S.A.; Sohrab, S.S.; Azhar, E.I.A. IgY antibodies for the immunoprophylaxis and therapy of respiratory infections. Hum. Vaccin. Immunoth. 2019, 15, 264-275. [CrossRef]

116. Peghin, M.; Danziger-Isakov, L. Prevention and treatment of respiratory virus infection. In Infectious Diseases in Solid-Organ Transplant Recipients, 1st ed.; Manuel, O., Ison, M.G., Eds.; Springer: Berlin/Heidelberg, Germany, 2019; pp. 107-129, ISBN 978-3-030-15394-6.

117. Lavelle, E.C.; Ward, R.W. Mucosal vaccines-Fortifying the frontiers. Nat. Rev. Immunol. 2021, 1-15. [CrossRef]

118. Sparrow, E.; Friede, M.; Sheikh, M.; Torvaldsen, S. Therapeutic antibodies for infectious diseases. Bull. World Health Organ. 2017, 95, 235-237. [CrossRef]

119. Berry, C.M. Antibody immunoprophylaxis and immunotherapy for influenza virus infection: Utilization of monoclonal or polyclonal antibodies? Hum. Vaccin. Immunoth. 2018, 14, 796-799. [CrossRef]

120. Rahman, S.; van Nguyen, S.; Icatlo, F.C., Jr.; Umeda, K.; Kodama, Y. Oral passive IgY-based immunotherapeutics: A novel solution for prevention and treatment of alimentary tract diseases. Hum. Vaccin. Immunoth. 2013, 9, 1039-1048. [CrossRef]

121. Zhang, X.; Calvert, R.A.; Sutton, B.J.; Doré, K.A. IgY: A key isotype in antibody evolution. Biol. Rev. Camb. Philos. Soc. 2017, 92, 2144-2156. [CrossRef]

122. Ikemori, Y.; Peralta, R.C.; Kuroki, M.; Yokoyama, H.; Kodama, Y. Research note: Avidity of chicken yolk antibodies to enterotoxigenic Escherichia coli fimbriae. Poult. Sci. 1993, 72, 2361-2365. [CrossRef] [PubMed]

123. Gassmann, M.; Thömmes, P.; Weiser, T.; Hübscher, U. Efficient production of chicken egg yolk antibodies against a conserved mammalian protein. FASEB J. 1990, 4, 2528-2532. [CrossRef] [PubMed]

124. Thomsen, K.; Christophersen, L.; Bjarnsholt, T.; Jensen, P.Ø.; Moser, C.; Høiby, N. Anti-Pseudomonas aeruginosa IgY antibodies augment bacterial clearance in a murine pneumonia model. J. Cyst. Fibros. 2016, 15, 171-178. [CrossRef]

125. Sudjarwo, S.A.; Eraiko, K.; Sudjarwo, G.W. Koerniasari. The potency of chicken egg yolk immunoglobulin (IgY) specific as immunotherapy to Mycobacterium tuberculosis infection. J. Adv. Pharm. Technol. Res. 2017, 8, 91-96. [PubMed]

126. Ferella, A.; Bellido, D.; Chacana, P.; Wigdorovitz, A.; dus Santos, M.J.; Mozgovoj, M.V. Chicken egg yolk antibodies against bovine respiratory syncytial virus neutralize the virus in vitro. Procedia Vaccinol. 2012, 6, 33-38. [CrossRef]

127. Fu, C.Y.; Huang, H.; Wang, X.-M.; Liu, Y.-G.; Wang, Z.-G.; Cui, S.-J.; Gao, H.-L.; Li, Z.; Li, J.-P.; Kong, X.-G. Preparation and evaluation of anti-SARS coronavirus IgY from yolks of immunized SPF chickens. J. Virol. Methods 2006, 133, 112-115. [CrossRef] [PubMed] 
128. Constantin, C.; Neagu, M.; Diana Supeanu, T.; Chiurciu, V.; Spandidos, D.A. IgY-Turning the page toward passive immunization in COVID-19 infection (Review). Exp. Ther. Med. 2020, 20, 151-158. [CrossRef]

129. Davey, P.; Wilcox, M.H.; Irving, W.; Thwaites, G. Chemoprophylaxis and immunization. In Antimicrobial Chemotherapy, 7th ed.; Davey, P., Wilcox, M.H., Irving, W., Thwaites, G., Eds.; Oxford University Press: Oxford, UK, 2015; ISBN 9780199689774.

130. Bradley, J.S. Chemoprophylaxis. In Principles and Practice of Pediatric Infectious Diseases, 4th ed.; Long, S.S., Ed.; Elsevier: Amsterdam, The Netherlands, 2012; pp. 68-76. ISBN 9781437727029.

131. Kausar, S.; Said Khan, F.; Ishaq Mujeeb Ur Rehman, M.; Akram, M.; Riaz, M.; Rasool, G.; Hamid Khan, A.; Saleem, I.; Shamim, S.; Malik, A. A review: Mechanism of action of antiviral drugs. Int. J. Immunopathol. Pharmacol. 2021, 35, 1-12. [CrossRef]

132. Batten, J. Chemoprophylaxis of respiratory infections. Postgrad. Med. J. 1976, 52, 571-575. [CrossRef]

133. Oxford, J.S. Chemoprophylaxis and Virus Infections of the Respiratory Tract, 1st ed.; Oxford, J.S., Ed.; CRC Press: Boca Raton, FL, USA, 2018; ISBN 9781351070614.

134. Minozzi, S.; Pifferi, S.; Brazzi, L.; Pecoraro, V.; Montrucchio, G.; D'Amico, R. Topical antibiotic prophylaxis to reduce respiratory tract infections and mortality in adults receiving mechanical ventilation. Cochrane Database Syst. Rev. 2021, 1, CD000022.

135. Grammatikos, A.; Albur, M.; Gompels, M.; Barnaby, C.L.; Allan, S.; Johnston, S. Antibiotic prophylaxis for the prevention of respiratory tract infections in antibody deficient patients: A retrospective cohort study. Clin. Infect. Pract. 2020, 7-8, 100048. [CrossRef]

136. Liberati, A.; D'Amico, R.; Pifferi, S.; Torri, V.; Brazzi, L.; Parmelli, E. Antibiotic prophylaxis to reduce respiratory tract infections and mortality in adults receiving intensive care. Cochrane Database Syst. Rev. 2009, 2009, CD000022.

137. Guitor, A.K.; Wright, G.D. Antimicrobial Resistance and Respiratory Infections. Chest 2018, 154, 1202-1212. [CrossRef] [PubMed]

138. Alshehhi, H.S.; Ali, A.A.; Jawhar, D.S.; Aly, E.M.; Swamy, S.; Fattah, M.A.; Drweesh, K.A.; Alsaadi, A. Assessment of implementation of antibiotic stewardship program in surgical prophylaxis at a secondary care hospital in Ras Al Khaimah, United Arab Emirates. Sci. Rep. 2021, 11, 1042. [CrossRef] [PubMed]

139. Tappenden, P.; Jackson, R.; Cooper, K.; Rees, A.; Simpson, E.; Read, R.; Nicholson, K. Amantadine, oseltamivir and zanamivir for the prophylaxis of influenza (including a review of existing guidance no. 67): A systematic review and economic evaluation. Health Technol. Assess. 2009, 13, 1-246. [CrossRef]

140. Prevention of SARS-CoV-2 Infection. Available online: https://www.covid19treatmentguidelines.nih.gov/overview/preventionof-sars-cov-2/ (accessed on 18 December 2021).

141. Shoumann, W.M.; Hegazy, A.A.; Nafae, R.M.; Ragab, M.I.; Samra, S.R.; Ibrahim, D.A.; Al-Mahrouky, T.H.; Sileem, A.E. Use of Ivermectin as a Potential Chemoprophylaxis for COVID-19 in Egypt: A Randomised Clinical Trial. J. Clin. Diagn. Res. 2021, 15, OC27-OC32. [CrossRef]

142. Omrani, M.; Keshavarz, M.; Nejad Ebrahimi, S.N.; Mehrabi, M.; McGaw, L.J.; Ali Abdalla, M.; Mehrbod, P. Potential Natural Products Against Respiratory Viruses: A Perspective to Develop Anti-COVID-19 Medicines. Front. Pharmacol. 2021, 11, 586993. [CrossRef]

143. Langeder, J.; Grienke, U.; Chen, Y.; Kirchmair, J.; Schmidtke, M.; Rollinger, J.M. Natural products against acute respiratory infections: Strategies and lessons learned. J. Ethnopharmacol. 2020, 248, 112298. [CrossRef]

144. Hensel, A.; Bauer, R.; Heinrich, M.; Spiegler, V.; Kayser, O.; Hempel, G.; Kraft, K. Challenges at the Time of COVID-19: Opportunities and Innovations in Antivirals from Nature. Planta Med. 2020, 86, 659-664. [CrossRef]

145. Chen, X.; Han, W.; Wang, G.; Zhao, X. Application prospect of polysaccharides in the development of anti-novel corona-virus drugs and vaccines. Int. J. Biol. Macromol. 2020, 164, 331-343. [CrossRef]

146. Alitongbieke, G.; Li, X.-M.; Wu, Q.-C.; Lin, Z.-C.; Huang, J.-F.; Xue, Y.; Liu, J.-N.; Lin, J.-M.; Pan, T.; Chen, Y.-X.; et al Effect of $\beta$-chitosan on the Binding Interaction between SARS-CoV-2 S-RBD and ACE2. PREPRINT. 2020. Available online: https: / / www.biorxiv.org/content/10.1101/2020.07.31.229781v3 (accessed on 24 October 2021).

147. Milewska, A.; Chi, Y.; Szczepanski, A.; Barreto-Duran, E.; Liu, K.; Liu, D.; Guo, X.; Ge, Y.; Li, J.; Cui, L.; et al. HTCC as a Highly Effective Polymeric Inhibitor of SARS-CoV-2 and MERS-CoV. Preprint. 2020. Available online: https://www.biorxiv.org/content/ 10.1101/2020.03.29.014183v1 (accessed on 24 October 2021)

148. Jang, Y.; Shin, H.; Lee, M.K.; Kwon, O.S.; Shin, J.S.; Kim, Y.-I.; Kim, C.W.; Lee, H.-R.; Kim, M. Antiviral activity of lamb-dacarrageenan against influenza viruses and severe acute respiratory syndrome coronavirus 2. Sci. Rep. 2021, 11, 821. [CrossRef] [PubMed]

149. Morokutti-Kurz, M.; Graf, C.; Prieschl-Grassauer, E. Amylmetacresol/2,4-dichlorobenzyl alcohol, hexylresorcinol, or carrageenan lozenges as active treatments for sore throat. Int. J. Gen. Med. 2017, 10, 53-60. [CrossRef] [PubMed]

150. Song, S.; Peng, H.; Wang, Q.; Liu, Z.; Dong, X.; Wen, C.; Ai, C.; Zhang, Y.; Wang, Z.; Zhu, B. Inhibitory activities of marine sulfated polysaccharides against SARS-CoV-2. Food Funct. 2020, 11, 7415-7420. [CrossRef] [PubMed]

151. Sun, Q.-L.; Li, Y.; Ni, L.-Q.; Li, Y.-X.; Cui, Y.-S.; Jiang, S.-L.; Xie, E.-Y.; Du, J.; Deng, F.; Dong, C.-X. Structural characterization and antiviral activity of two fucoidans from the brown algae Sargassum henslowianum. Carbohydr. Polym. 2020, $229,115487$. [CrossRef]

152. Wang, W.; Wu, J.; Zhang, X.; Hao, C.; Zhao, X.; Jiao, G.; Shan, X.; Tai, W.; Yu, G. Inhibition of Influenza A Virus Infection by Fucoidan Targeting Viral Neuraminidase and Cellular EGFR Pathway. Sci. Rep. 2017, 7, 40760. [CrossRef]

153. Chang, R.; Ng, T.B.; Sun, W.-Z. Lactoferrin as potential preventative and adjunct treatment for COVID-19. Int. J. Antimicrob. Agents 2020, 56, 106118. [CrossRef] 
154. Salaris, C.; Scarpa, M.; Elli, M.; Bertolini, A.; Guglielmetti, S.; Pregliasco, F.; Blandizzi, C.; Brun, P.; Castagliuolo, I. Protective Effects of Lactoferrin against SARS-CoV-2 Infection In Vitro. Nutrients 2021, 13, 328. [CrossRef]

155. Chauhan, P.; Kumar, A. Development of a microbial coating for cellulosic surface using aloe vera and silane. Carbohydr. Polym. Technol. Appl. 2020, 1, 100015. [CrossRef]

156. Meneguzzo, F.; Ciriminna, R.; Zabini, F.; Pagliaro, M. Review of Evidence Available on Hesperidin-Rich Products as Potential Tools against COVID-19 and Hydrodynamic Cavitation-Based Extraction as a Method of Increasing Their Production. Processes 2020, 8, 549. [CrossRef]

157. Cheng, L.; Zheng, W.; Li, M.; Huang, J.; Bao, S.; Xu, Q.; Ma, Z. Citrus Fruits Are Rich in Flavonoids for Immunoregulation and Potential Targeting ACE2. PREPRINT (Version 1). 2020. Available online: https://www.preprints.org/manuscript/202002.0313/ v1 (accessed on 26 October 2021).

158. Omar, S.; Bouziane, I.; Bouslama, Z.; Djemel, A. In-Silico Identification of Potent Inhibitors of COVID-19 Main Protease (Mpro) and Angiotensin Converting Enzyme 2 (ACE2) from Natural Products: Quercetin, Hispidulin, and Cirsimaritin Ex-hibited Better Potential Inhibition than Hydroxy-Chloroquine against COVID-19 Main Protease Active Site and ACE2. 2020. Available online: https:/ / chemrxiv.org/engage/chemrxiv/article-details/60c74a53469df45440f43d21 (accessed on 26 October 2021).

159. Joshi, R.S.; Jagdale, S.S.; Bansode, S.B.; Shankar, S.S.; Tellis, M.B.; Pandya, V.K.; Chugh, A.; Giri, A.P.; Kulkarni, M.J. Discovery of potential multi-target-directed ligands by targeting host-specific SARS-CoV-2 structurally conserved main protease. J. Biomol. Struct. Dyn. 2021, 39, 3099-3114. [CrossRef]

160. Wahedi, H.M.; Ahmad, S.; Abbasi, S.W. Stilbene-based natura lompounds as promising drug candidates against COVID-19. J. Biomol. Struct. Dyn. 2020, 39, 3225-3234. [PubMed]

161. Chen, H.; Du, Q. Potential Natural Compounds for Preventing SARS-CoV-2 (2019-nCoV) Infection. 2020. Available online: https:/ / www.preprints.org/manuscript/202001.0358/v3 (accessed on 26 October 2021).

162. Maurya, V.K.; Kumar, S.; Prasad, A.K.; Bhatt, M.L.B.; Saxena, S.K. Structure-based drug designing for potential antiviral activity of selected natural products from Ayurveda against SARS-CoV-2 spike glycoprotein and its cellular receptor. Virus Dis. 2020, 31, 179-193. [CrossRef] [PubMed]

163. Sa-Ngiamsuntorn, K.; Suksatu, A.; Pewkliang, Y.; Thongsri, P.; Kanjanasirirat, P.; Manopwisedjaroen, S.; Charoensut-thivarakul, S.; Wongtrakoongate, P.; Pitiporn, S.; Chaopreecha, J.; et al. Anti-SARS-CoV-2 Activity of Andrographis paniculata Extract and Its Major Component Andrographolide in Human Lung Epithelial Cells and Cyto-toxicity Evaluation in Major Organ Cell Representatives. J. Nat. Prod. 2021, 84, 1261-1270. [CrossRef] [PubMed]

164. Guo, C.; Zhu, Z.; Yu, P.; Zhang, X.; Dong, W.; Wang, X.; Chen, Y.; Liu, X. Inhibitory effect of iota-carrageenan on porcine reproductive and respiratory syndrome virus in vitro. Antivir. Ther. 2019, 24, 261-270. [CrossRef]

165. Wang, W.; Zhang, P.; Yu, G.-L.; Li, C.-X.; Hao, C.; Qi, X.; Zhang, L.-J.; Guan, H.-S. Preparation and anti-influenza A virus activity of K-carrageenan oligosaccharide and its sulphated derivatives. Food Chem. 2012, 133, 880-888. [CrossRef]

166. Ter Ellen, B.M.; Kumar, N.D.; Bouma, E.M.; Troost, B.; van de Pol, D.P.I.; van der Ende-Metselaar, H.; Nawijn, M. Resveratrol and Pterostilbene Potentlyinhibit SARS-CoV-2 Infection in Vitro. 2020. Available online: https://www.biorxiv.org/content/10.1101/ 2020.09.24.285940v1 (accessed on 27 October 2021).

167. Pasquereau, S.; Nehme, Z.; Haidar Ahmad, S.; Daouad, F.; van Assche, J.; Wallet, C.; Schwartz, C.; Rohr, O.; Morot-Bizot, S.; Herbein, G. Resveratrol Inhibits HCoV-229E and SARS-CoV-2 Coronavirus Replication In Vitro. Viruses 2021, 13, 354. [CrossRef]

168. Cinatl, J.; Morgenstern, B.; Bauer, G.; Chandra, P.; Rabenau, H.; Doerr, H.W. Glycyrrhizin, an active component of liquo-rice roots, and replication of SARS-associated coronavirus. Lancet 2003, 361, 2045-2046. [CrossRef]

169. Gupta, S.; Mishra, K.P.; Ganju, L. Broad-spectrum antiviral properties of andrographolide. Arch. Virol. 2017, 162, 611-623. [CrossRef]

170. Muralidharan, A.; Russell, M.S.; Larocque, L.; Gravel, C.; Sauvé, S.; Chen, Z.; Li, C.; Chen, W.; Cyr, T.; Rosu-Myles, M.; et al. Chitosan alters inactivated respiratory syncytial virus vaccine elicited immune responses without affecting lung histopathology in mice. Vaccine 2019, 37, 4031-4039. [CrossRef]

171. Aucoin, M.; Cooley, K.; Saunders, P.R.; Carè, J.; Anheyer, D.; Medina, D.N.; Cardozo, V.; Remy, D.; Hannan, N.; Garber, A. The effect of Echinacea spp. on the prevention or treatment of COVID-19 and other respiratory tract infections in hu-mans: A rapid review. Adv. Integr. Med. 2020, 7, 203-217. [CrossRef]

172. Zhang, P.; Wang, J.; Wang, W.; Liu, X.; Liu, H.; Li, X.; Wu, X. Astragalus polysaccharides enhance the immune response to avian infectious bronchitis virus vaccination in chickens. Microb. Pathog. 2017, 111, 81-85. [CrossRef]

173. Zhang, P.; Liu, X.; Liu, H.; Wang, W.; Liu, X.; Li, X.; Wu, X. Astragalus polysaccharides inhibit avian infectious bronchitis virus infection by regulating viral replication. Microb. Pathog. 2018, 114, 124-128. [CrossRef] [PubMed]

174. Garg, P.; Singh, P.; Verma, K. Remdesivir break replication of virus \& Rhodiola rosea acts same by enhancing immunity. Int. J. Sci. Eng. Res. 2020, 11, 817-825.

175. El-Sekaily, A.; Helal, M.; Saad, A. Enhancement of immune tolerance of COVID19 patients might be achieved with alginate supplemented therapy. Int. J. Cancer Biomed. Res. 2020, 4, 21-26.

176. Abdullahi, A.Y.; Kallon, S.; Yu, X.; Zhang, Y.; Li, G. Vaccination with Astragalus and Ginseng Polysaccharides Improves Immune Response of Chickens against H5N1 Avian Influenza Virus. Biomed. Res. Int. 2016, 2016, 1510264. [CrossRef]

177. Zaharoff, D.A.; Rogers, C.J.; Hance, K.W.; Schlom, J.; Greiner, J.W. Chitosan solution enhances both humoral and cell-mediated immune responses to subcutaneous vaccination. Vaccine 2007, 25, 2085-2094. [CrossRef] 
178. Ghendon, Y.; Markushin, S.; Krivtsov, G.; Akopova, I. Chitosan as an adjuvant for parenterally administered inactivated influenza vaccines. Arch. Virol. 2008, 153, 831-837. [CrossRef]

179. Bolhassani, A.; Talebi, S.; Anvar, A. Endogenous and Exogenous Natural Adjuvants for Vaccine Development. Mini Rev. Med. Chem. 2017, 17, 1442-1456. [CrossRef]

180. Zhang, Y.-Q.; Tsai, Y.-C.; Monie, A.; Hung, C.-F.; Wu, T.-C. Carrageenan as an adjuvant to enhance peptide-based vaccine potency. Vaccine 2010, 28, 5212-5219. [CrossRef]

181. Hao, Q.; Dong, B.R.; Wu, T. Probiotics for preventing acute upper respiratory tract infections. Cochrane Database Syst. Rev. 2015, CD006895. [CrossRef]

182. Ahanchian, H.; Jafari, S.A. Probiotics and prebiotics for prevention of viral respiratory tract infections. In Probiotics, Prebiotics, and Synbiotics, 1st ed.; Watson, R., Preedy, V., Eds.; Academic Press: Cambridge, MA, USA, 2016; pp. 575-583, ISBN 9780128023716.

183. Bourdillon, A.T.; Edwards, H.A. Review of probiotic use in otolaryngology. Am. J. Otolaryngol. 2021, 42, 102883. [CrossRef] [PubMed]

184. Darbandi, A.; Asadi, A.; Ghanavati, R.; Afifirad, R.; Darb Emamie, A.; Kakanj, M.; Talebi, M. The effect of probiotics on respiratory tract infection with special emphasis on COVID-19: Systemic review 2010-20. Int. J. Infect. Dis. 2021, 105, 91-104. [CrossRef] [PubMed]

185. Gohil, K.; Samson, R.; Dastager, S.; Dharne, M. Probiotics in the prophylaxis of COVID-19: Something is better than nothing. 3 Biotech. 2021, 11, 1. [CrossRef] [PubMed]

186. Vouloumanou, E.K.; Makris, G.C.; Karageorgopoulos, D.E.; Falagas, M.E. Probiotics for the prevention of respiratory tract infections: A systematic review. Int. J. Antimicrob. Agents 2009, 34, 197.e1-197.e10. [CrossRef] [PubMed]

187. Verma, A.; Xu, K.; Du, T.; Zhu, P.; Liang, Z.; Liao, S.; Zhang, J.; Raizada, M.K.; Grant, M.B.; Li, Q. Expression of Human ACE2 in Lactobacillus and Beneficial Effects in Diabetic Retinopathy in Mice. Mol. Ther. Methods Clin. Dev. 2019, 14, 161-170. [CrossRef]

188. Khanzada, H.; Salam, A.; Qadir, M.B.; Phan, D.-N.; Hassan, T.; Munir, M.U.; Pasha, K.; Hassan, N.; Khan, M.Q.; Kim, I.S. Fabrication of Promising Antimicrobial Aloe Vera/PVA Electrospun Nanofibers for Protective Clothing. Materials 2020, 13, 3884. [CrossRef]

189. Buluş, E.; Buluş, G.S.; Yakuphanoğlu, F. Production of polylactic acid activated charcoal nanofiber membranes for COVID-19 pandemic by electrospinning technique and determination of filtration efficiency. J. Mater. Electron. Devices 2020, 4, 21-26.

190. Leung, W.W.F.; Sun, Q. Electrostatic charged nanofiber filter for filtering airborne novel coronavirus (COVID-19) and nanoaerosols. Sep. Purif. Technol. 2020, 250, 116886. [CrossRef]

191. Zhang, Q.; Honko, A.; Zhou, J.; Gong, H.; Downs, S.N.; Vasquez, J.H.; Fang, R.H.; Gao, W.; Griffiths, A.; Zhang, L. Cellular nanosponges inhibit SARS-CoV-2 infectivity. Nano Lett. 2020, 20, 5570-5574. [CrossRef]

192. Surnar, B.; Kamran, M.Z.; Shah, A.S.; Dhar, S. Clinically approved antiviral drug in an orally administrable nanoparticle for COVID-19. ACS Pharmacol. Transl. Sci. 2020, 3, 1371-1380. [CrossRef]

193. Pardi, N.; Hogan, M.J.; Porter, F.W.; Weissman, D. mRNA vaccines-A new era in vaccinology. Nat. Rev. Drug Discov. 2018, 17, 261-279. [CrossRef]

194. Kauffman, K.J.; Webber, M.J.; Anderson, D.G. Materials for non-viral intracellular delivery of messenger RNA therapeutics. J. Control. Release 2016, 240, 227-234. [CrossRef] [PubMed]

195. Illum, L. Nasal drug delivery-Possibilities, problems and solutions. J. Control. Release 2003, 87, 187-198. [CrossRef]

196. Maaz, A.; Blagbrough, I.S.; de Bank, P.A. In Vitro Evaluation of Nasal Aerosol Depositions: An Insight for Direct Nose to Brain Drug Delivery. Pharmaceutics 2021, 13, 1079. [CrossRef] [PubMed]

197. Madav, Y.; Wairkar, S. Strategies for enhanced direct nose-to-brain drug delivery. In Direct Nose-to-Brain Drug Delivery, 1st ed.; Pardeshi, C.V., Souto, E.B., Eds.; Academic Press: Cambridge, MA, USA, 2021; pp. 169-184, ISBN 9780128225226.

198. Hua, S. Advances in Nanoparticulate Drug Delivery Approaches for Sublingual and Buccal Administration. Front. Pharmacol. 2019, 10, 1328. [CrossRef] [PubMed]

199. Smart, J.D. Buccal drug delivery. Expert Opin. Drug Deliv. 2005, 2, 507-517. [CrossRef]

200. Czerkinsky, C.; Holmgren, J. Topical immunization strategies. Mucosal. Immunol. 2010, 3, 545-555. [CrossRef]

201. Pabst, R. Mucosal vaccination by the intranasal route. Nose-associated lymphoid tissue (NALT)-Structure, function and species differences. Vaccine 2015, 33, 4406-4413. [CrossRef]

202. Date, Y.; Ebisawa, M.; Fukuda, S.; Shima, H.; Obata, Y.; Takahashi, D.; Kato, T.; Hanazato, M.; Nakato, G.; Williams, I.R.; et al. NALT M cells are important for immune induction for the common mucosal immune system. Int. Immunol. 2017, 29, 471-478. [CrossRef]

203. Shakya, A.K.; Chowdhury, M.Y.E.; Tao, W.; Gill, H.S. Mucosal vaccine delivery: Current state and a pediatric perspective. J. Control. Release 2016, 240, 394-413. [CrossRef]

204. Patil, M. Mucoadhesion as a strategy to enhance the direct nose-to-brain drug delivery. In Direct Nose-to-Brain Drug Delivery, 1st ed.; Pardeshi, C.V., Souto, E.B., Eds.; Academic Press: Cambridge, MA, USA, 2021; pp. 115-156. ISBN 9780128225226.

205. Sudhakar, Y.; Kuotsu, K.; Bandyopadhyay, A.K. Buccal bioadhesive drug delivery-A promising option for orally less efficient drugs. J. Control. Release 2006, 114, 15-40. [CrossRef]

206. Roy, S.; Pal, K.; Anis, A.; Pramanik, K.; Prabhakar, B.R. Polymers in Mucoadhesive Drug-Delivery Systems: A Brief Note. Des. Monomers Polym. 2009, 12, 483-495. [CrossRef] 
207. Hanif, M.; Zaman, M.; Qureshi, S. Thiomers: A Blessing to Evaluating Era of Pharmaceuticals. Int. J. Polym. Sci. 2015, 2015, 146329. [CrossRef]

208. Bernkop-Schnürch, A. Thiomers: A new generation of mucoadhesive polymers. Adv. Drug Deliv. Rev. 2005, 57, 1569-1582. [CrossRef]

209. Brannigan, R.P.; Khutoryanskiy, V.V. Progress and Current Trends in the Synthesis of Novel Polymers with Enhanced Mucoadhesive Properties. Macromol. Biosci. 2019, 19, 1900194. [CrossRef] [PubMed]

210. Shan, X.; Aspinall, S.; Kaldybekov, D.B.; Buang, F.; Williams, A.C.; Khutoryanskiy, V.V. Synthesis and Evaluation of Methacrylated Poly(2-ethyl-2-oxazoline) as a Mucoadhesive Polymer for Nasal Drug Delivery. ACS Appl. Polym. Mater. 2021, 3, $5882-5892$. [CrossRef]

211. Gennari, C.G.M.; Sperandeo, P.; Polissi, A.; Minghetti, P.; Cilurzo, F. Lysozyme Mucoadhesive Tablets Obtained by Freeze-Drying. J. Pharm. Sci. 2019, 108, 3667-3674. [CrossRef] [PubMed]

212. Dreijer-van der Glas, S.; Hafner, A. Nose. In Practical Pharmaceutics: An International Guideline for the Preparation, Care and Use of Medicinal Products, 1st ed.; Bouwman-Boer, Y., Fenton-May, V., le Brun, P., Eds.; Springer: Berlin/Heidelberg, Germany, 2015; pp. 139-152, ISBN 978-3-319-15813-6.

213. Al-Ghananeem, A.M.; Sandefer, E.P.; Doll, W.J.; Page, R.C.; Chang, Y.; Digenis, G.A. Gamma scintigraphy for testing bioequivalence: A case study on two cromolyn sodium nasal spray preparations. Int. J. Pharm. 2008, 357, 70-76. [CrossRef]

214. Newman, S.P.; Pitcairn, G.R.; Dalby, R.N. Drug delivery to the nasal cavity: In vitro and in vivo assessment. Crit. Rev. Ther. Drug Carr. Syst. 2004, 21, 21-66. [CrossRef]

215. Djupesland, P.G. Nasal drug delivery devices: Characteristics and performance in a clinical perspective-a review. Drug Deliv. Transl. Res. 2013, 3, 42-62. [CrossRef]

216. Rygg, A.; Hindle, M.; Longest, P.W. Linking Suspension Nasal Spray Drug Deposition Patterns to Pharmacokinetic Profiles: A Proof-of-Concept Study Using Computational Fluid Dynamics. J. Pharm. Sci. 2016, 105, 1995-2004. [CrossRef] [PubMed]

217. Tiozzo Fasiolo, L.; Manniello, M.D.; Tratta, E.; Buttini, F.; Rossi, A.; Sonvico, F.; Bortolotti, F.; Russo, P.; Colombo, G. Opportunity and challenges of nasal powders: Drug formulation and delivery. Eur. J. Pharm. Sci. 2018, 113, 2-17. [CrossRef] [PubMed]

218. Mahdi, M.H.; Conway, B.R.; Smith, A.M. Development of mucoadhesive sprayable gellan gum fluid gels. Int. J. Pharm. 2015, 488, 12-19. [CrossRef] [PubMed]

219. Sherafudeen, S.P.; Vasantha, P.V. Development and evaluation of in situ nasal gel formulations of loratadine. Res. Pharm. Sci. 2015, 10, 466-476. [PubMed]

220. Cassano, R.; Servidio, C.; Trombino, S. Biomaterials for Drugs Nose-Brain Transport: A New Therapeutic Approach for Neurological Diseases. Materials 2021, 14, 1802. [CrossRef]

221. Kouchak, M. In situ gelling systems for drug delivery. Jundishapur J. Nat. Pharm. Prod. 2014, 9, e20126. [CrossRef]

222. Saindane, N.S.; Pagar, K.P.; Vavia, P.R. Nanosuspension based in situ gelling nasal spray of carvedilol: Development, in vitro and in vivo characterization. AAPS PharmSciTech 2013, 14, 189-199. [CrossRef]

223. Thakkar, H.; Vaghela, D.; Patel, B.P. Brain targeted intranasal in-situ gelling spray of paroxetine: Formulation, characterization and in-vivo evaluation. J. Drug Deliv. Sci. Technol. 2021, 62, 102317. [CrossRef]

224. Bianculli, R.H.; Mase, J.D.; Schulz, M.D. Antiviral Polymers: Past Approaches and Future Possibilities. Macromolecules 2020, 53, 9158-9186. [CrossRef]

225. Tratnjek, L.; Sibinovska, N.; Kristan, K.; Kreft, M.E. In Vitro Ciliotoxicity and Cytotoxicity Testing of Repeated Chronic Exposure to Topical Nasal Formulations for Safety Studies. Pharmaceutics 2021, 13, 1750. [CrossRef]

226. Meinhardt, J.; Radke, J.; Dittmayer, C.; Franz, J.; Thomas, C.; Mothes, R.; Laue, M.; Schneider, J.; Brünink, S.; Greuel, S.; et al Olfactory transmucosal SARS-CoV-2 invasion as a port of central nervous system entry in individuals with COVID-19. Nat. Neurosci. 2021, 24, 168-175. [CrossRef] [PubMed]

227. Sjölinder, H.; Jonsson, A.B. Olfactory nerve-A novel invasion route of Neisseria meningitidis to reach the meninges. PLoS ONE 2010, 5, e14034. [CrossRef] [PubMed]

228. Herbert, R.P.; Harris, J.; Chong, K.P.; Chapman, J.; West, A.K.; Chuah, M.I. Cytokines and olfactory bulb microglia in response to bacterial challenge in the compromised primary olfactory pathway. J. Neuroinflamm. 2012, 9, 109. [CrossRef] [PubMed]

229. Lin, C.-W.; Chen, Y.-T.; Ho, H.-H.; Hsieh, P.-S.; Kuo, Y.-W.; Lin, J.-H.; Liu, C.-R.; Huang, Y.-F.; Chen, C.-W.; Hsu, C.-H.; et al. Lozenges with probiotic strains enhance oral immune response and health. Oral Dis. 2021, 00, 1-10. [CrossRef]

230. Pattanshetty, S.; Narayana, A.; Radhakrishnan, R. Povidone-iodine gargle as a prophylactic intervention to interrupt the transmission of SARS-CoV-2. Oral Dis. 2021, 27, 752-753. [CrossRef]

231. Shewale, J.G.; Gelhaus, H.C.; Ratcliff, J.L.; Hernandez-Kapila, Y.L. In vitro antiviral activity of stabilized chlorine dioxide containing oral care products. Oral Dis. 2021, 00, 1-8. [CrossRef]

232. Schütz, D.; Conzelmann, C.; Fois, G.; Groß, R.; Weil, T.; Wettstein, L.; Stenger, S.; Zelikin, A.; Hoffmann, T.K.; Frick, M.; et al. Carrageenan-containing over-the-counter nasal and oral sprays inhibit SARS-CoV-2 infection of airway epithelial cultures. Am. J. Physiol. Lung Cell. Mol. Physiol. 2021, 320, L750-L756. [CrossRef]

233. Mattes, R.D. Physiologic responses to sensory stimulation by food: Nutritional implications. J. Am. Diet. Assoc. 1997, 97, 406-413 [CrossRef]

234. Campos, J.C.; Cunha, D.; Ferreira, D.C.; Reis, S.; Costa, P.J. Oromucosal precursors of in loco hydrogels for wound-dressing and drug delivery in oral mucositis: Retain, resist, and release. Mater. Sci. Eng. C. Mater. Biol. Appl. 2021, 118, 111413. [CrossRef] 
235. Dreijer-van der Glas, S. Oropharynx. In Practical Pharmaceutics: An International Guideline for the Preparation, Care and Use of Medicinal Products, 1st ed.; Bouwman-Boer, Y., Fenton-May, V., le Brun, P., Eds.; Springer: Berlin/Heidelberg, Germany, 2015; pp. 131-138, ISBN 978-3-319-15813-6.

236. Hassan, A.O.; Kafai, N.M.; Dmitriev, I.P.; Fox, J.M.; Smith, B.K.; Harvey, I.B.; Chen, R.E.; Winkler, E.S.; Wessel, A.W.; Case, J.B.; et al. A Single-Dose Intranasal ChAd Vaccine Protects Upper and Lower Respiratory Tracts against SARS-CoV-2. Cell 2020, 183, 169-184. [CrossRef]

237. An, X.; Martinez-Paniagua, M.; Rezvan, A.; Sefat, S.R.; Fathi, M.; Singh, S.; Biswas, S.; Pourpak, M.; Yee, C.; Liu, X.; et al. Singledose intranasal vaccination elicits systemic and mucosal immunity against SARS-CoV-2. iScience 2021, 24, 103037. [CrossRef]

238. Bricker, T.L.; Darling, T.L.; Hassan, A.O.; Harastani, H.H.; Soung, A.; Jiang, X.; Dai, Y.-N.; Zhao, H.; Adams, L.J.; Holtzman, M.J.; et al. A single intranasal or intramuscular immunization with chimpanzee adenovirus-vectored SARS-CoV-2 vaccine protects against pneumonia in hamsters. Cell Rep. 2021, 36, 109400. [CrossRef] [PubMed]

239. Hassan, A.O.; Feldmann, F.; Zhao, H.; Curiel, D.T.; Okumura, A.; Tang-Huau, T.-L.; Case, J.B.; Meade-White, K.; Calli-son, J.; Chen, R.E.; et al. A single in-tranasal dose of chimpanzee adenovirus-vectored vaccine protects against SARS-CoV-2 infection in rhesus macaques. Cell Rep. Med. 2021, 2, 100230. [CrossRef] [PubMed]

240. Van Doremalen, N.; Purushotham, J.N.; Schulz, J.E.; Holbrook, M.G.; Bushmaker, T.; Carmody, A.; Port, J.R.; Yinda, C.K.; Okumura, A.; Saturday, G.; et al. Intranasal ChAdOx1 nCoV-19/AZD1222 Vaccination Reduces Shed-Ding of SARS-CoV-2 D614G in Rhesus Macaques. 2021. Available online: https://www.biorxiv.org/content/10.1101/2021.01.09.426058v1 (accessed on 26 November 2021).

241. A Study of Intranasal ChAdOx1 nCOV-19. Available online: https:/ / clinicaltrials.gov/ct2/show /NCT04816019?term=chadox1 + ncov-19+intranasal\&draw $=2 \&$ rank $=1$ (accessed on 26 November 2021).

242. King, R.G.; Silva-Sanchez, A.; Peel, J.N.; Botta, D.; Meza-Perez, S.; Allie, R.; Schultz, M.D.; Liu, M.; Bradley, J.E.; Qiu, S.; et al. Single-dose Intranasal Administration of AdCOVID Elicits Systemic and Mucosal Immunity Against SARS-CoV-2 in Mice. 2020. Available online: https:/ / www.biorxiv.org/content/10.1101/2020.10.10.331348v1 (accessed on 26 November 2021).

243. Nasal Spray Vaccine for Covid-19. Available online: https://www.clinicaltrialsarena.com/comment/nasal-spray-vaccine-covid19/ (accessed on 26 November 2021).

244. Safety and Immunogenicity of an Intranasal RSV Vaccine Expressing SARS-CoV-2 Spike Protein (COVID-19 Vaccine) in Adults. Available online: https: / / clinicaltrials.gov / ct2/ show / NCT04798001?term=meissa+vaccines\&draw=2\&rank=2 (accessed on 27 November 2021).

245. Chavda, V.P.; Vora, L.K.; Pandya, A.K.; Patravale, V.B. Intranasal vaccines for SARS-CoV-2: From challenges to potential in COVID-19 management. Drug Discov. Today 2021, 26, 2619-2636. [CrossRef] [PubMed]

246. Intravacc Announces Positive Pre-clinical Data for Its SARS-CoV-2 Nose Spray Vaccine. Available online: https://www intravacc.nl/news/intravacc-announces-positive-pre-clinical-data-intranasal-sars-cov-2-candidate-vaccine/ (accessed on 27 November 2021).

247. Ku, Z.; Xie, X.; Hinton, P.R.; Liu, X.; Ye, X.; Muruato, A.E.; Ng, D.C.; Biswas, S.; Zou, J.; Liu, Y.; et al. Nasal delivery of an IgM offers broad protection from SARS-CoV-2 variants. Nature 2021, 595, 718-723. [CrossRef]

248. Ku, Z.; Xie, X.; Davidson, E.; Ye, X.; Su, H.; Menachery, V.D.; Li, Y.; Yuan, Z.; Zhang, X.; Muruato, A.E.; et al. Molecular determinants and mechanism for antibody cocktail preventing SARS-CoV-2 escape. Nat. Commun. 2021, 12, 469. [CrossRef]

249. Zhang, H.; Yang, Z.; Xiang, J.; Cui, Z.; Liu, J.; Liu, C. Intranasal Administration of SARS-CoV-2 Neutralizing Human Antibody Prevents Infection in mice. 2020. Available online: https:/ / www.biorxiv.org/content/10.1101/2020.12.08.416677v1 (accessed on 30 November 2021).

250. Eureka Therapeutics Announces Successful Preclinical Results of InvisiMask ${ }^{\mathrm{TM}}$ Human Antibody Nasal Spray against SARSCoV-2 Infection. Available online: https://www.eurekatherapeutics.com/media/press-releases/121420/ (accessed on 30 November 2021).

251. Lepelletier, D.; Maillard, J.Y.; Pozzetto, B.; Simon, A. Povidone Iodine: Properties, Mechanisms of Action, and Role in Infection Control and Staphylococcus aureus Decolonization. Antimicrob. Agents Chemother. 2020, 64, e00682-20. [CrossRef]

252. Carrouel, F.; Gonçalves, L.S.; Conte, M.P.; Campus, G.; Fisher, J.; Fraticelli, L.; Gadea-Deschamps, E.; Ottolenghi, L.; Bourgeois, D. Antiviral Activity of Reagents in Mouth Rinses against SARS-CoV-2. J. Dent. Res. 2021, 100, 124-132. [CrossRef]

253. Anderson, D.E.; Sivalingam, V.; Kang, A.E.Z.; Ananthanarayanan, A.; Arumugam, H.; Jenkins, T.M.; Hadjiat, Y.; Eggers, M. Povidone-iodine demonstrates rapid in vitro virucidal activity against SARS-CoV-2, the virus causing COVID-19 disease. Infect. Dis. Ther. 2020, 9, 669-675. [CrossRef]

254. Hassandarvish, P.; Tiong, V.; Sazaly, A.B.; Mohamed, N.A.; Arumugam, H.; Ananthanarayanan, A.; Qasuri, M.; Hadjiat, Y. Povidone iodine gargle and mouthwash. Br. Dent. J. 2020, 228, 900. [CrossRef]

255. Challacombe, S.J.; Kirk-Bayley, J.; Sunkaraneni, V.S.; Combes, J. Povidone iodine. Br. Dent. J. 2020, 228, 656-657. [CrossRef] [PubMed]

256. Bidra, A.S.; Pelletier, J.S.; Westover, J.B.; Frank, S.; Brown, S.M.; Tessema, B. Rapid In-Vitro Inactivation of Severe Acute Respiratory Syndrome Coronavirus 2 (SARS-CoV-2) Using Povidone-Iodine Oral Antiseptic Rinse. J. Prosthodont. 2020, 29, 529-533. [CrossRef] [PubMed] 
257. Martínez Lamas, L.; Diz Dios, P.; Pérez Rodríguez, M.T.; del Campo Pérez, V.; Cabrera Alvargonzalez, J.J.; López Domínguez, A.M.; Fernandez Feijoo, J.; Diniz Freitas, M.; Limeres Posse, J. Is povidone iodine mouthwash effective against SARS-CoV-2? First in vivo tests. Oral Dis. 2020, 00,1-4. [CrossRef] [PubMed]

258. Effect of Local Treatment (Carrageenan Nasal Spray and PVP-I Mouthwash) in Reducing Viral Load in Patients with COVID-19 (LT-COVID19). Available online: https:/ / clinicaltrials.gov/ct2/show /NCT05049213?term=carrageenan\&cond=SARS-CoV2 + Infection\&draw $=2 \&$ rank=5 (accessed on 1 December 2021).

259. Arefin, M.K. Povidone Iodine (PVP-I) Oro-Nasal Spray: An Effective Shield for COVID-19 Protection for Health Care Worker (HCW), for all. Indian J. Otolaryngol. Head Neck Surg. 2021, 1-6. [CrossRef] [PubMed]

260. Hasan, M.J.; Rumi, S.K.N.F.; Banu, S.S.; Uddin, A.K.M.N.; Islam, M.S.; Arefin, M.K. Virucidal effect of povidone iodine on COVID-19 in the nasopharynx: A structured summary of a study protocol for an open-label randomized clinical trial. Trials 2021, 22, 2. [CrossRef] [PubMed]

261. Young, R. Chlorine Dioxide (CLO2) As a Non-Toxic Antimicrobial Agent for Virus, Bacteria and Yeast (Candida Albicans). Int. J. Vaccines Vaccin. 2016, 2, 52. [CrossRef]

262. Giarratana, N.; Rajan, B.; Kamala, K.; Mendenhall, M.; Reiner, G. A sprayable Acid-Oxidizing solution containing hypochlorous acid (AOS2020) efficiently and safely inactivates SARS-Cov-2: A new potential solution for upper respiratory tract hygiene. Eur. Arch. Otorhinolaryngol. 2021, 278, 3099-3103. [CrossRef]

263. Use of Hypochlorous Acid as Prophylaxis in Health Personnel at High Risk of Infection by SARS-CoV 2 (COVID19). Available online: https: / clinicaltrials.gov / ct2/show / NCT04684550?term=HCLO\&cond=SARS (accessed on 4 December 2021).

264. Shmuel, K.; Dalia, M.; Tair, L.; Yaakov, N. Low pH Hypromellose (Taffix) nasal powder spray could reduce SARS-CoV-2 infection rate post mass-gathering event at a highly endemic community: An observational prospective open label user survey. Expert Rev. Anti-Infect. Ther. 2021, 19, 1325-1330. [CrossRef]

265. Bentley, K.; Stanton, R.J. Hydroxypropyl Methylcellulose-Based Nasal Sprays Effectively Inhibit In Vitro SARS-CoV-2 Infection and Spread. Viruses 2021, 13, 2345. [CrossRef]

266. Paull, J.R.A.; Heery, G.P.; Bobardt, M.D.; Castellarnau, A.; Luscombe, C.A.; Fairley, J.K.; Gallay, P.A. Virucidal and antiviral activity of astodrimer sodium against SARS-CoV-2 in vitro. Antiviral Res. 2021, 191, 105089. [CrossRef]

267. Paull, J.R.A.; Luscombe, C.A.; Castellarnau, A.; Heery, G.P.; Bobardt, M.D.; Gallay, P.A. Protective Effects of Astodrimer Sodium 1\% Nasal Spray Formulation against SARS-CoV-2 Nasal Challenge in K18-hACE2 Mice. Viruses 2021, 13, 1656. [CrossRef] [PubMed]

268. Pyrć, K.; Milewska, A.; Duran, E.B.; Botwina, P.; Dabrowska, A.; Jedrysik, M.; Benedyk, M.; Lopes, R.; Arenas-Pinto, A.; Badr, M.; et al. SARS-CoV-2 inhibition using a mucoadhesive, amphiphilic chitosan that may serve as an anti-viral nasal spray. Sci Rep. 2021, 11, 20012. [CrossRef]

269. Effectiveness of a Novel Respirator with Chitosan Nanoparticles. Available online: https://clinicaltrials.gov/ct2/show/NCT044 90200 (accessed on 5 December 2021).

270. Koenighofer, M.; Lion, T.; Bodenteich, A.; Prieschl-Grassauer, E.; Grassauer, A.; Unger, H.; Mueller, C.A.; Fazekas, T. Carrageenan nasal spray in virus confirmed common cold: Individual patient data analysis of two randomized controlled trials. Multidiscip. Respir. Med. 2014, 9, 57. [CrossRef]

271. Eccles, R.; Winther, B.; Johnston, S.L.; Robinson, P.; Trampisch, M.; Koelsch, S. Efficacy and safety of iota-carrageenan nasal spray versus placebo in early treatment of the common cold in adults: The ICICC trial. Respir. Res. 2015, 16, 121. [CrossRef] [PubMed]

272. Prophylaxis Covid-19 in Healthcare Agents by Intensive Treatment with Ivermectin and Iota-carrageenan (Ivercar-Tuc). Available online: https: / / clinicaltrials.gov/ct2/show / NCT04701710?term=carrageenan\&cond=SARS-CoV2+Infection\&draw=2\&rank=3 (accessed on 7 December 2021).

273. Carrageenan Nasal Spray for COVID-19 Prophylaxis (ICE-COVID). Available online: https:/ / clinicaltrials.gov/ct2/show / NCT0 4590365? term $=$ carrageenan\&cond=SARS-CoV2 + Infection\&draw $=2 \& r a n k=4$ (accessed on 7 December 2021).

274. Leibbrandt, A.; Meier, C.; König-Schuster, M.; Weinmüllner, R.; Kalthoff, D.; Pflugfelder, B.; Graf, P.; Frank-Gehrke, B.; Beer, M.; Fazekas, T.; et al. Iota-carrageenan is a potent inhibitor of influenza A virus infection. PLoS ONE 2010, 5, e14320. [CrossRef] [PubMed]

275. Usefulness of Topic Ivermectin and Carrageenan to Prevent Contagion of Covid 19 (IVERCAR). Available online: https:// clinicaltrials.gov/ct2/show / results / NCT04425850?term=carrageenan\&cond=SARS-CoV2+Infection\&draw=2\&rank=2 (accessed on 13 December 2021).

276. Efficacy of a Nasal Spray Containing Iota-Carrageenan in the Prophylaxis of COVID-19 Disease in Health Personnel Dedicated to Patients Care With COVID-19 Disease (CARR-COV-02). Available online: https: / / clinicaltrials.gov/ct2/show / NCT04521322? term $=$ carrageenan\&cond=SARS-CoV2+Infection\&draw=2\&rank=1 (accessed on 13 December 2021).

277. Prophylactic Treatment with Carragelose Nasal Spary to Prevent SARS-CoV-2, COVID-19, Infections in Health Care Workers. Available online: https: / / clinicaltrials.gov / ct2/show /NCT04681001?term=carrageenan\&cond=SARS-CoV2+Infection\&draw= 2\&rank=6 (accessed on 13 December 2021).

278. Bansal, S.; Jonsson, C.B.; Taylor, S.L.; Figueroa, J.M.; Dugour, A.V.; Palacios, C.; Vega, J.C. Iota-carrageenan and xylitol inhibit SARS-CoV-2 in Vero cell culture. PLoS ONE 2021, 16, e0259943. [CrossRef] [PubMed] 
279. Campione, E.; Lanna, C.; Cosio, T.; Rosa, L.; Conte, M.P.; Iacovelli, F.; Romeo, A.; Falconi, M.; del Vecchio, C.; Franchin, E.; et al. Lactoferrin as Antiviral Treatment in COVID-19 Management: Preliminary Evidence. Int. J. Environ. Res. Public Health 2021, 18, 10985. [CrossRef]

280. Campione, E.; Cosio, T.; Rosa, L.; Lanna, C.; di Girolamo, S.; Gaziano, R.; Valenti, P.; Bianchi, L. Lactoferrin as Protective Natural Barrier of Respiratory and Intestinal Mucosa against Coronavirus Infection and Inflammation. Int. J. Mol. Sci. 2020, $21,4903$. [CrossRef]

281. Winchester, S.; John, S.; Jabbar, K.; John, I. Clinical efficacy of nitric oxide nasal spray (NONS) for the treatment of mild COVID-19 infection. J. Infect. 2021, 83, 237-279. [CrossRef]

282. Garren, M.R.; Ashcraft, M.; Qian, Y.; Douglass, M.; Brisbois, E.J.; Handa, H. Nitric oxide and viral infection: Recent developments in antiviral therapies and platforms. Appl. Mater. Today 2021, 22, 100887. [CrossRef]

283. Meng, Z.; Wang, T.; Chen, L.; Chen, X.; Li, L.; Qin, X.; Li, H.; Luo, J. The Effect of Recombinant Human Interferon Alpha Nasal Drops to Prevent COVID-19 Pneumonia for Medical Staff in an Epidemic Area. Curr. Top. Med. Chem. 2021, 21, $920-927$. [CrossRef]

284. Lee, A.C.; Jeong, Y.; Lee, S.; Jang, H.; Zheng, A.; Kwon, S.; Repine, J.E. Nasopharyngeal Type-I Interferon for Immediately Available Prophylaxis Against Emerging Respiratory Viral Infections. Front. Immunol. 2021, 12, 660298. [CrossRef]

285. Alibek, K.; Tskhay, A. Ahead of a vaccine: A safe method of protection against COVID-19 exists. Res. Ideas Outcomes 2020, 6, e61709. [CrossRef]

286. Cannon, M.L.; Westover, J.B.; Bleher, R.; Sanchez-Gonzalez, M.A.; Ferrer, G. In Vitro Analysis of the Anti-viral Potential of Nasal Spray Constituents against SARS-CoV-2. 2020. Available online: https://www.biorxiv.org/content/10.1101/2020.12.02.408575v3 (accessed on 13 December 2021).

287. Kontiokari, T.; Uhari, M.; Koskela, M. Antiadhesive effects of xylitol on otopathogenic bacteria. J. Antimicrob. Chemother. 1998 41, 563-565. [CrossRef]

288. A Study to Evaluate the Efficacy of Xlear vs. Placebo for Acute COVID-19 Infection. Available online: https://clinicaltrials.gov / ct2/show / NCT04858620 (accessed on 13 December 2021).

289. Gudmundsdottir, Á.; Scheving, R.; Lindberg, F.; Stefansson, B. Inactivation of SARS-CoV-2 and HCoV-229E In Vitro by ColdZyme ${ }^{\circledR}$ a medical device mouth spray against the common cold. J. Med. Virol. 2021, 93, 1792-1795. [CrossRef]

290. Davison, G.; Perkins, E.; Jones, A.W.; Swart, G.M.; Jenkins, A.R.; Robinson, H.; Dargan, K. Coldzyme ${ }^{\circledR}$ Mouth Spray reduces duration of upper respiratory tract infection symptoms in endurance athletes under free living conditions. Eur. J. Sport Sci. 2021, 21,771-780. [CrossRef]

291. Posch, W.; Vosper, J.; Zaderer, V.; Noureen, A.; Constant, S.; Bellmann-Weiler, R.; Lass-Flörl, C.; Wilflingseder, D. ColdZyme Maintains Integrity in SARS-CoV-2-Infected Airway Epithelia. mBio 2021, 12, e00904-21. [CrossRef]

292. Nagai, M.; Moriyama, M.; Ichinohe, T. Oral Bacteria Combined with an Intranasal Vaccine Protect from Influenza A Virus and SARS-CoV-2 Infection. mBio 2021, 12, e0159821. [CrossRef]

293. Paolacci, S.; Ceccarini, M.R.; Codini, M.; Manara, E.; Tezzele, S.; Percio, M.; Capodicasa, N.; Kroni, D.; Dundar, M.; Ergoren, M.C.; et al. Pilot study for the evaluation of safety profile of a potential inhibitor of SARS-CoV-2 endocytosis. Acta Biomed. 2020, 91, e2020009.

294. Efficacy and Safety of Longan Extract Spray (P80 Spray) in Volunteers with Coronavirus Disease 2019 (COVID-19). Available online: https:/ / clinicaltrials.gov/ct2/show / study / NCT04887233 (accessed on 15 December 2021).

295. Gugleva, V.; Ivanova, N.; Sotirova, Y.; Andonova, V. Dermal Drug Delivery of Phytochemicals with Phenolic Structure via Lipid-Based Nanotechnologies. Pharmaceuticals 2021, 14, 837. [CrossRef]

296. Bioflavonoid Spray Efficacy Against Respiratory Viruses. Available online: https://www.oralhealthgroup.com/features/ bioflavonoid-spray-efficacy-against-respiratory-viruses / (accessed on 15 December 2021).

297. Godinho, P.I.C.; Soengas, R.G.; Silva, V.L.M. Therapeutic Potential of Glycosyl Flavonoids as Anti-Coronaviral Agents. Pharmaceuticals 2021, 14, 546. [CrossRef]

298. Proud, P.C.; Tsitoura, D.; Watson, R.J.; Chua, B.Y.; Aram, M.J.; Bewley, K.R.; Cavell, B.E.; Cobb, R.; Dowall, S.; Fotheringham, S.A.; et al. Prophylactic intranasal administration of a TLR2/ 6 agonist reduces upper respiratory tract viral shedding in a SARS-CoV-2 challenge ferret model. EBioMedicine 2021, 63, 103153. [CrossRef]

299. Deliyannis, G.; Wong, C.Y.; McQuilten, H.A.; Bachem, A.; Clarke, M.; Jia, X.; Horrocks, K.; Zeng, W.; Girkin, J.; Scott, N.E.; et al. TLR2-mediated activation of innate responses in the upper airways confers antiviral protection of the lungs. JCI Insight 2021, 6, e140267. [CrossRef]

300. Pilicheva, B.; Boyuklieva, R. Can the Nasal Cavity Help Tackle COVID-19? Pharmaceutics 2021, 13, 1612. [CrossRef]

301. Zaidi, A.K.; Dehgani-Mobaraki, P. Retracted article: The mechanisms of action of Ivermectin against SARS-CoV-2: An evidencebased clinical review article. J. Antibiot. 2021, 75, 1-13. [CrossRef]

302. Jokicevic, K.; Kiekens, S.; Byl, E.; de Boeck, I.; Cauwenberghs, E.; Lebeer, S.; Kiekens, F. Probiotic nasal spray development by spray drying. Eur. J. Pharm. Biopharm. 2021, 159, 211-220. [CrossRef]

303. Almanza-Reyes, H.; Moreno, S.; Plascencia-López, I.; Alvarado-Vera, M.; Patrón-Romero, L.; Borrego, B.; Reyes-Escamilla, A.; Valencia-Manzo, D.; Brun, A.; Pestryakov, A.; et al. Evaluation of silver nanoparticles for the prevention of SARS-CoV-2 infection in health workers: In vitro and in vivo. PLOS ONE 2021, 16, e0256401. 
304. Jeremiah, S.S.; Miyakawa, K.; Morita, T.; Yamaoka, Y.; Ryo, A. Potent antiviral effect of silver nanoparticles on SARS-CoV-2. Biochem. Biophys. Res. Commun. 2020, 533, 195-200. [CrossRef]

305. Colunga Biancatelli, R.M.L.; Berrill, M.; Catravas, J.D.; Marik, P.E. Quercetin and Vitamin C: An Experimental, Synergistic Therapy for the Prevention and Treatment of SARS-CoV-2 Related Disease (COVID-19). Front. Immunol. 2020, 11, 1451. [CrossRef]

306. Williamson, G.; Kerimi, A. Testing of natural products in clinical trials targeting the SARS-CoV-2 (Covid-19) viral spike proteinangiotensin converting enzyme-2 (ACE2) interaction. Biochem. Pharmacol. 2020, 178, 114123. [CrossRef]

307. Dejani, N.N.; Elshabrawy, H.A.; Bezerra Filho, C.d.S.M.; de Sousa, D.P. Anticoronavirus and Immunomodulatory Phenolic Compounds: Opportunities and Pharmacotherapeutic Perspectives. Biomolecules 2021, 11, 1254. [CrossRef]

308. Rossi, G.A.; Sacco, O.; Capizzi, A.; Mastromarino, P. Can Resveratrol-Inhaled Formulations Be Considered Potential Adjunct Treatments for COVID-19? Front. Immunol. 2021, 12, 670955. [CrossRef]

309. Da Silva, J.K.R.; Figueiredo, P.L.B.; Byler, K.G.; Setzer, W.N. Essential oils as antiviral agents. Potential of essential oils to treat SARS-CoV-2 infection: An in-silico investigation. Int. J. Mol. Sci. 2020, 21, 3426. [CrossRef]

310. Asif, M.; Saleem, M.; Saadullah, M.; Yaseen, H.S.; Al Zarzour, R. COVID-19 and therapy with essential oils having antiviral, anti-inflammatory, and immunomodulatory properties. Inflammopharmacology 2020, 28, 1153-1161. [CrossRef]

311. Wińska, K.; Mączka, W.; Łyczko, J.; Grabarczyk, M.; Czubaszek, A.; Szumny, A. Essential Oils as Antimicrobial Agents-Myth or Real Alternative? Molecules 2019, 24, 2130. [CrossRef] [PubMed]

312. Thuy, B.T.P.; My, T.T.A.; Hai, N.T.T.; Hieu, L.T.; Hoa, T.T.; Thi Phuong Loan, H.; Triet, N.T.; Anh, T.T.V.; Quy, P.T.; Tat, P.V.; et al. Investigation into SARS-CoV-2 Resistance of Compounds in Garlic Essential Oil. ACS Omega 2020, 5, 8312-8320. [CrossRef]

313. Baker, N.; Williams, A.J.; Tropsha, A.; Ekins, S. Repurposing Quaternary Ammonium Compounds as Potential Treatments for COVID-19. Pharm. Res. 2020, 37, 104. [CrossRef]

314. Abdulrab, S.; Alkadasi, B.; Al-Maweri, S.; Halboub, E.; Alhadainy, H.; Geerts, G. Statins-based prophylactic mouthwash and nasal spray may protect against coronavirus disease 2019. New Microbes New Infect. 2020, 37, 100751. [CrossRef]

315. Vofo, G.; Brodie, R.; Gross, M. Nasal lavage containing Angiotensin-Converting Enzyme-2 agonist can prevent and reduce viral load in COVID-19. Med. Hypotheses 2020, 144, 110207. [CrossRef]

316. Yoon, J.G.; Yoon, J.; Song, J.Y.; Yoon, S.Y.; Lim, C.S.; Seong, H.; Noh, J.Y.; Cheong, H.J.; Kim, W.J. Clinical Significance of a High SARS-CoV-2 Viral Load in the Saliva. J. Korean Med. Sci. 2020, 35, e195. [CrossRef]

317. Aydemir, D.; Ulusu, N.N. Correspondence: Angiotensin-converting enzyme 2 coated nanoparticles containing respiratory masks, chewing gums and nasal filters may be used for protection against COVID-19 infection. Travel Med. Infect. Dis. 2020, $37,101697$. [CrossRef] [PubMed]

318. Herrera, D.; Serrano, J.; Roldán, S.; Sanz, M. Is the oral cavity relevant in SARS-CoV-2 pandemic? Clin. Oral Investig. 2020, 24, 2925-2930. [CrossRef] [PubMed]

319. Bidra, A.S.; Pelletier, J.S.; Westover, J.B.; Frank, S.; Brown, S.M.; Tessema, B. Comparison of in vitro inactivation of SARS CoV-2 with hydrogen peroxide and povidone-iodine oral antiseptic rinses. J. Prosthodont. 2020, 29, 599-603. [CrossRef] [PubMed] 